
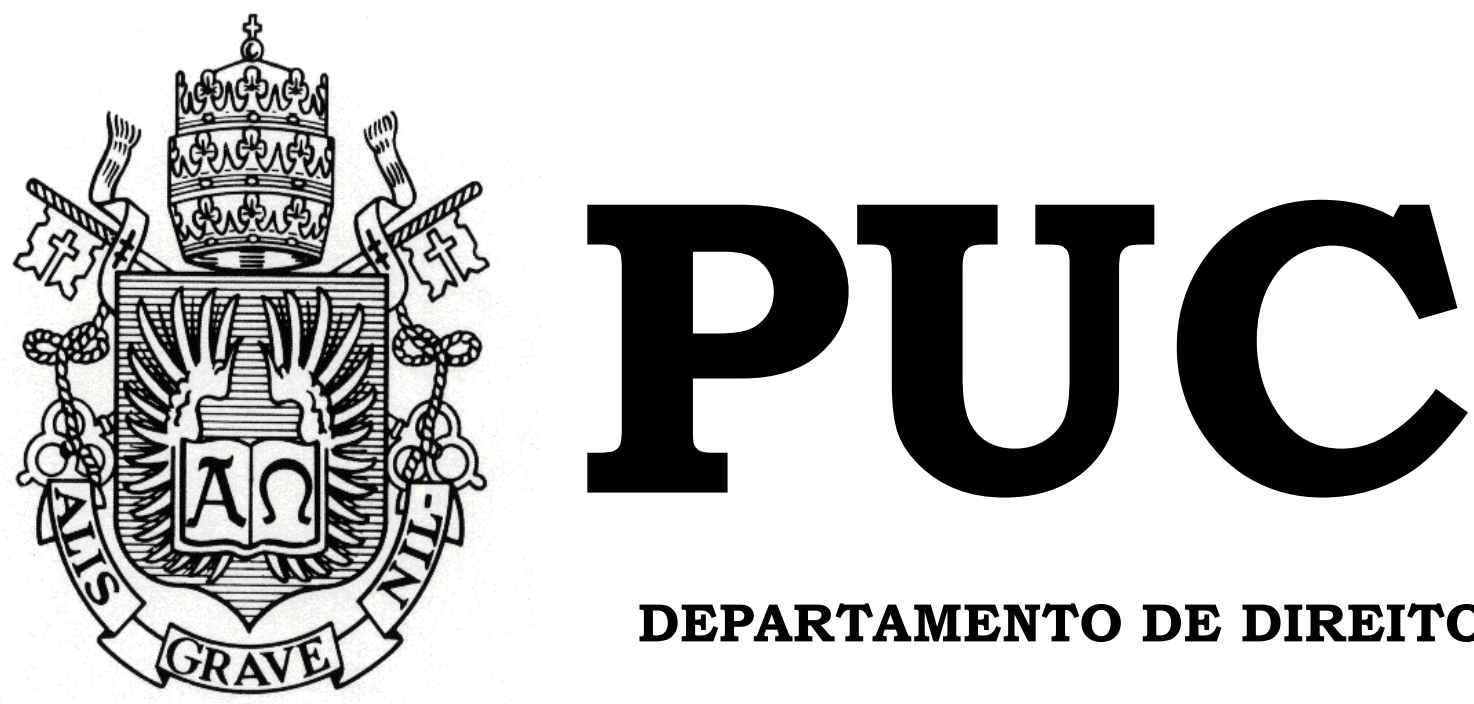

DEPARTAMENTO DE DIREITO

\title{
LIMITAÇÕES AO PODER DE REFORMA CONSTITUCIONAL
}

por

\section{ABNER BARROCO VELLASCO AUSTIN}

ORIENTADOR :

Thiago Varella

2014.2

PONTIFÍCIA UNIVERSIDADE CATÓLICA DO RIO DE JANEIRO RUA MARQUÊS DE SÃO VICENTE, 225 - CEP 22453-900 RIO DE JANEIRO - BRASIL 


\title{
LIMITAÇÕES AO PODER DE REFORMA CONSTITUCIONAL
}

\author{
por
}

\section{ABNER BARROCO VELLASCO AUSTIN}

Monografia apresentada ao

Departamento de Direito da

Pontifícia Universidade Católica do

Rio de Janeiro (PUC-Rio) para a obtenção do Título de Bacharel em Direito.

Orientador : Thiago Varella 


\section{Agradecimentos}

À minha avó Glória, exemplo de ternura, carinho e amor que com imensa dedicação ofereceu a sua vida em prol da família, dedico-lhe a minha eterna gratidão pelo acolhimento e por permitir que eu fosse mais um de seus filhos.

À minha mãe, Zezé, que me deu todo o carinho e amor, porto seguro, a quem admiro por ter conduzido toda a nossa família nos momentos de maiores dificuldades e que pelos seus ensinamentos, dedicação e cuidado transmitiu todos os valores que carrego na vida.

Ao meu pai, José Carlos Austin, modelo de pai e homem a quem tenho imensa sorte e orgulho de ser filho. Sua vida inteira foi construída a base de trabalho incessante para garantir uma vida digna a toda família, entretanto, nunca perdeu o bom humor e jamais deixou de transmitir alegria a todos que o cercam.

À minha irmã, Alana Vellasco, mais forte que os laços fraternos que nos unem, estão os laços de amizade que seguirão pelo resto de nossas vidas.

Á Maurício Abelha, meu anjo da guarda, por ter tornado o irreal em real, o impossível em possível e um destino improvável em uma vida rodeada de felicidade. Minha gratidão eterna.

Ao meu grande amigo Francisco Eduardo Costa da Silva, por me fazer conhecer os caminhos do direito e por ter enveredado lado a lado nos caminhos da vida. 
À minha namorada, Mariana, por todo carinho e dedicação e pelo incentivo diário para elaboração deste trabalho. Quaisquer palavras e dedicatórias não seriam boas o suficiente para descrever o meu amor por você.

Aos professores da Pontifícia Universidade Católica que despertaram o meu amor pela ciência do direito constitucional em especial ao meu mestre e orientador, Professor orientador Thiago Varella.

Ao Professor Dante Limongi, cujas palavras e preocupação sempre lembrarei.

Ao professor José Ribas Vieira pelas preciosas orientações durante o período de monitoria em Teoria do Estado, por ter despertado de forma ainda mais firme o desejo pelo estudo da ciência constitucional.

A todos os amigos que tive a honra de fazer durante a graduação em especial a Isabella Benevides pelo auxílio ao longo da graduação e pela luxuosa contribuição para minha monografia.

À Pontifícia Universidade Católica do Rio de Janeiro, pelo ensino, oportunidades e por ajudar a me transformar como pessoa. "Alis grave nil"!

A todos que conviveram comigo na sociedade Teixeira Duarte Advogados, pela amizade e ensinamentos que tornaram o exercício prático do direito um desafio constante e enriquecedor, em especial na pessoa do Dr. Carlos Adolfo Teixeira Duarte, profissional exemplar que foi e será fundamental para minha formação pessoal e profissional.

E, por fim, dedico essa monografia a todos aqueles que sofreram e lutaram para dar a vida à Carta Constitucional Cidadã de 1988. Dedico 
também a todos aqueles membros da sociedade que lutam diariamente para manter no seio da Constituição os valores e direitos garantidos pelo legislador constituinte de 1988 e que por vezes tentam ser malbaratados nos infindáveis processos de emenda à constituição. 
"Todos os direitos da humanidade foram consquistados na luta; todas as regras importantes do direito devem ter sido, na sua origem, arrancadas àquelas que a elas se opunham, e todo o direito, direito de um povo ou direito de um particular faz presumir que se esteja decido a mantê-lo com firmeza. $O$ direito não é uma pura teoria, mas uma força viva. Por isso a justiça sustenta numa das mãos a balança em que pesa o direito, e na outra a espada de a que se serve para o defender"

(Dr. Rudolf Von Jhering)

“A Constituição não é assunto restrito aos juristas, aos sábios ou aos políticos. Não poder ser ato de algumas elites. É responsabilidade de todo o povo. Daí a preocupação de que ela não surja no açodamento, mas resulte de uma profunda reflexão nacional.

Os deputados constituintes, mandatários da soberania popular, saberão redigir uma Carta Política ajustada às circunstâncias históricas. Clara e imperativa em seus princípios, a Constituição deverá ser flexível quanto ao modo, para que as crises políticas conjunturais sejam contidas na inteligência da lei.” (Tancredo Neves) 


\section{Resumo}

O escopo da presente monografia abrange a importância do estudo das limitações ao poder de reforma da constituição - com enfoque prevalente nas limitações adotadas historicamente pelo legislador constituinte brasileiro, sem, contudo, deixar de ser analisada as limitações constitucionais existentes no âmbito do direito estrangeiro - para o estudo da ciência do direito constitucional, objetivando obter uma melhor compreensão dos modelos que são comumente adotados pelos legisladores constituintes para buscar uma maior perenidade das constituições. Nesse contexto, teremos que necessariamente abordar o conceito de "poder constituinte" que sempre foi considerada uma questão fundamental para o pensamento moderno e que afeta sobremaneira na concepção dos limites ao legislador constituinte derivado no processo de elaboração da reforma da constituição. Iremos também efetuar uma análise das espécies de limitações que são impostas ao legislador constituinte derivado ao exercer a tarefa que lhe foi confiada pelo legislador constituinte originário para proceder à alteração do texto constitucional.

\section{Palavras chave:}

Direito Constitucional - Teoria do Poder Constituinte - Poder Constituinte Originário - Poder Constituinte Derivado - Poder Decorrente Constituição Federal -Supremo Tribunal Federal - Direito Estrangeiro Limitações ao poder de reforma constitucional - Revisão Constitucional Emenda à Constituição. 


\section{SUMÁRIO}

Introdução

Capítulo I - Teoria do Poder Constiuinte

1.1 - Considerações iniciais acerca da importância do estudo da teoria do poder constituinte para se compreender o processo regular de reforma constitucional

1.2.1 - Características do Poder Constituinte originário

1.2.2 - A Legitimidade e a Titularidade do Poder Constituinte originário

1.2.3 - Formas de Exercício do Poder Constituinte originário 35

1.2.4 - Limitações ao Poder Constituinte originário 43

Capítulo II - O Poder Constituinte Derivado

2.1.1 - Considerações iniciais acerca do Poder Constituinte derivado 53

2.1.2 - Características do Poder Constituinte derivado 53

2.1.3 - Formas de Exercício do Poder Constituinte derivado

2.1.4 - Poder Constituinte derivado decorrente

2.1.5 - Limitações Constitucionais ao Poder Constituinte derivado decorrente $\quad 58$

2.1.6 - Poder Constituinte derivado reformador 62

2.1.7 - Espécies de Limitação ao Poder Constituinte derivado de reforma 
2.1. 8 - As limitações materiais ao Poder Constituinte Derivado de reforma 65

2.1. 9 - As limitações materiais na Constituição Federal de 1988 74

2.1.10 - As limitações temporais ao Poder de Reforma da Constituição 79

2.1.11 - As limitações Circunstanciais ao Poder de Reforma da Constituição 80

2.1.12 - As limitações Formais ao Poder de Reforma da Constituição 83

Conclusão 86

Bibliografia 89 


\section{LISTA DE ABREVIAÇÕES E SIGLAS}

Id.: Idem

$\mathrm{n}^{\mathrm{o}}$ : Número

Op. Cit.: Opus Citatum

p.: Página/Páginas

par.: Parágrafo

STF: Supremo Tribunal Federal 


\title{
Introdução
}

As sociedades se organizam de acordo com os seus ideais políticos, históricos, sociais, e, via de regra, se materializam na criação de uma "Constituição", documento jurídico e político, que regula todo o ordenamento jurídico do Estado.

O professor Gilmar Ferreira Mendes ${ }^{1}$, ao discorrer sobre a influência da Constituição na realidade social, utilizou a introdução do livro do professor colombiano Ricardo Guibourg ${ }^{2}$ :

\begin{abstract}
"O estudo das Constituição é fascinante pelo poder que se acorda às suas normas sobre a vida das relações sociais.

Em prólogo de um livro colombiano, com título, de ressonância austiana, 'Como fazer coisas com a Constituição', Ricardo Guibourg, assombrado com tantas consequências que um tratamento leviano da Lei mais importante de um país pode gerar para o quotidiano dos cidadãos, advertiu, combinando o bom humor com seriedade, que 'com a Constituição se podem mesmo fazer muitas coisas; nem todas aceitáveis nem todas honoráveis'.
\end{abstract}

Em virtude desta característica "fundamental" da Constituição para organização da sociedade, como apontada pelo professor, que se torna essencial o estudo do exercício deste Poder Constituinte originário que é capaz de "fazer muitas coisas; nem todas aceitáveis nem todas honoráveis", para que se possa perquirir se o exercício deste poder foi efetivado pelo seu real titular, ou seja, se a ordem jurídica estatal é legítima e também para analisar quais seriam as eventuais limitações a este Poder Constituinte que "tudo pode". Por fim, iremos abordar como a doutrina constitucionalista vêm estudando o exercício e as características fundamentais deste "Poder Constituinte".

\footnotetext{
${ }^{1}$ MENDES, Gilmar Ferreira \& BRANCO, Paulo Gustavo Gonet. Curso de Direito Constitucional. 8 ed. revisada e atualizada. São Paulo: Editora: Saraiva, 2013. p. 37.

${ }^{2}$ MENDONÇA, Daniel. Analisis constitucional: uma introducción -cómo hacer cosas com la Constitución,Bogotá, Editora: Editoral Universidade del Rosario, 2002. p.12.
} 
Esses temas serão analisados no capítulo I da presente monografia, entretanto, sempre tendo em mente a implicação prática do estudo teórico acerca do "Poder Constituinte originário" como limitação ao "Poder Constituinte derivado", para que possa ser analisado, de igual modo, como deve se proceder as alterações e reformas ao texto constitucional, sem, entretanto, macular o ideário político e jurídico que serviram como norte para a criação do texto constitucional que regulará a vida dos cidadãos de determinada sociedade.

Entretanto, com o passar do tempo, deve ser reconhecido, que surgem novas necessidades, e, os indivíduos passam a pleitear cada vez mais direitos perante o Estado e buscam aperfeiçoar por todos os meios o ordenamento jurídico para que a "Constituição escrita" esteja de acordo com a "Constituição real" que simboliza a realidade social sempre cambiante da sociedade.

Nesse sentido, é essencial que seja estudado os mecanismos de exercício do "Poder Constituinte derivado" para que sejam efetuadas as alterações no texto constitucional, de modo que, não seja necessária uma "revolução" com o rompimento contínuo da ordem jurídica para que os cidadãos possam ver garantidos os seus direitos fundamentais.

Com efeito, no Capítulo II é apresentada a natureza jurídica, as características, a forma de exercício, a legitimidade, a titularidade deste "Poder Constituinte derivado" e também será analisado como a doutrina constitucionalista pátria e estrangeira (em especial os juristas lusitanos) aborda o tema acerca de quais são as limitações existentes ao poder de reforma constitucional para que não ocorra a "fraude à Constituição", mecanismo que deve ser repudiado por todos os juristas e operadores do direito, haja vista que se trata de alteração do texto constitucional por um 
meio inadequado, ou seja, sem o exercício do seu legítimo titular que é detentor do exercício do "Poder Constituinte originário".

São esses os temas que pretendemos abordar na presente monografia, ao longo de dois capítulos divididos entre a "Teoria do Poder Constituinte" e "Poder Constituinte Derivado". 


\section{Capítulo I - Teoria do Poder Constituinte}

\section{1 - Considerações iniciais acerca da importância do estudo da teoria do poder constituinte para se compreender o processo regular de reforma constitucional}

É de fundamental importância o estudo da "Teoria do Poder Constituinte" para uma melhor compreensão do nosso ordenamento jurídico. Ainda que possamos diferenciar com clareza o estudo da teoria do Poder Constituinte originário e as limitações constitucionais impostas as manifestações posteriores deste poder como a "revisão constitucional", a "reforma constitucional" e a competência constituinte que pode ser exercida pelos Estados-membros da federação (Poder Constituinte derivado decorrente), ainda assim, entendemos que o estudo isolado das "Limitações ao poder de reforma da Constituição" dissociado de um estudo pressuposto e necessário da "Teoria do Poder Constituinte" torna a compreensão deste primeiro tema imprecisa, confusa e pouco completa. Nesse sentido, segue abaixo o posicionamento adotado pelo professor André Ramos Tavares ${ }^{3}$ :

"Pensamos que, quanto mais minuciosamente for estudado o problema da
formação da ordem jurídica, mais consciência teremos de seus limites, da razão de sua existência e de quais sejam os seus efeitos legítimos".

Podemos afirmar que o posicionamento majoritário que predomina no âmbito da doutrina constitucionalista é no sentido que o Poder Constituinte pode ser divido em duas espécies distintas: o Poder Constituinte originário e o Poder Constituinte derivado (ou reformador) 4 . Em linhas gerais, devemos considerar que ambas as espécies nada mais são do que formas distintas de manifestação do mesmo fenômeno jurídicopolítico que estão abrangidos no gênero que podemos definir como "Teoria geral do poder constituinte", tema que será estudado mais detidamente neste

\footnotetext{
${ }^{3}$ TAVARES, Andre Ramos. Curso de Direito Constitucional. São Paulo: Editora: Saraiva, 2002. p. 52.

${ }^{4}$ ZIMMERMANN, Augusto. Curso de Direito Constitucional. 3 ed. Rio de Janeiro: Editora Lumen Juris, 2004. p. 150 .
} 
primeiro capítulo, em especial no que concerne às suas origens, ao exercício e a limitação a este Poder Constituinte originário.

Para fins de conceituação, podemos considerar que o Poder Constituinte é o poder de elaborar o texto da nova constituição, criando, por conseguinte, a nova ordem jurídica do Estado que serve como substituta da Constituição e da ordem jurídica anterior de determinado Estado. ${ }^{5}$

Por outro turno, os professores Celso Ribeiro Bastos e Ives Gandra Martins $^{6}$ destacam que o Poder Constituinte configura-se numa "função". Esta função, para os citados autores, é a de elaborar as regras de uma nova Constituição, mas para estes autores no fenômeno da "reforma constitucional" também há manifestação do poder constituinte (que é o designado "Poder Constituinte derivado").

Segue nessa mesma linha de raciocínio, um dos maiores estudiosos sobre esse tema, o professor Antonio $\mathrm{Negri}^{7}$, que sob o prisma da ciência jurídica conceitua o poder constituinte:

"É a fonte de produção das normas constitucionais, ou seja, o poder de fazer uma constituição e assim ditar as normas fundamentais que organizam os poderes do Estado. Em outros termos, é o poder de instaurar um novo ordenamento jurídico e, com isto, regular as relações jurídicas no seio de uma nova comunidade".

As definições dos autores acima elencadas de "Poder Constituinte" se confundem muitas vezes com a própria conceituação do "Poder Constituinte originário". Podemos afirmar que os autores, ao abordarem o tema do "Poder Constituinte" de forma genérica, acabam por identificar a expressão mais "forte" deste poder que consiste no "Poder Constituinte originário", razão pela qual as conceituações muitas vezes acabam por se confundir.

\footnotetext{
${ }^{5}$ ZIMMERMANN, Augusto. Curso de Direito Constitucional. 3 ed. Rio de Janeiro: Editora Lumen Juris, 2004. p. 150.

${ }^{6}$ BASTOS, Celso Ribeiro; MARTINS, Ives Gandra, Comentários á Constituição do Brasil. São Paulo: Editora Saraiva, 1988, v. 1. p.143.

${ }^{7}$ NEGRI, Antonio. O poder constituinte: ensaio sobre alternativas da modernidade, traduação Adriano Pilatti. Rio de Janeiro: Editora DPeA, 2002. p. 8.
} 
Nesse sentido, colacionamos a definição de "Poder Constituinte originário", muito parecida com as conceituações de "Poder Constituinte" acima destacadas. Nesse sentido segue abaixo o posicionamento do professor Alexandre de Moraes ${ }^{8}$ :

"O poder constituinte originário estabelece a Constituição de um novo Estado, organizando-o e criando os poderes destinados a reger os interesses de uma comunidade. Tanto haverá Poder Constituinte no surgimento de uma primeira Constituição, quanto na elaboração de qualquer Constituição posterior".

Convém salientar, que não pretendemos esgotar neste tópico todos os aspectos que envolvem o "Poder Constituinte originário" e o "Poder Constituinte derivado", haja vista que ambos os temas serão estudados ao longo do presente trabalho de forma mais detalhada, haja vista que o presente trabalho objetiva apenas explicitar a importância desta teoria para compreendermos ao final de forma mais clara as "limitações ao poder de reforma constitucional”. Em síntese, vamos aqui apenas tracejar os pontos iniciais para que possamos enquadrá-los dentro da "Teoria do Poder Constituinte".

Podemos conceituar o Poder Constituinte derivado reformador como aquele poder que foi designado pela Constituição (ou seja pelo Poder Constituinte originário) para proceder à sua reforma, objetivando efetuar uma atualização dos seus valores para que a Constituição possa se manter condizente com a realidade social. ${ }^{9}$ No Brasil, ainda temos uma nova manifestação do "Poder Constituinte derivado" que consiste no Poder Decorrente, que é a possibilidade dos Estados-Membros, em respeito aos princípios da autonomia e do "pacto federativo", elaborarem as suas Constituições Estaduais respeitando os limites impostos pela Constituição Federal.

\footnotetext{
${ }^{8}$ MORAES, Alexandre de, Direito Constitucional. 21 ed . São Paulo: Editora: Atlas, 2007. p. 22.

${ }^{9}$ ZIMMERMANN, Augusto. Curso de Direito Constitucional. 3 ed. Rio de Janeiro: Editora Lumen Juris, 2004. p. 150.
} 
Conforme foi observado por Genaro R. Carrió ${ }^{10}$ o Poder Constituinte derivado se contrapõe ao Poder Constituinte originário, pois, é uma "criatura" deste, tal como o é o Poder Executivo, Legislativo e o Judiciário.

O professor José Afonso da Silva ${ }^{11}$, adotando o conceito do professor Manoel Ferreira Filho qualifica o poder constituinte de revisão como:

"É aquele poder, inerente à Constituição rígida que se destina a modificar essa Constituição segundo o que a mesma estabelece. $\mathrm{Na}$ verdade, o Poder Constituinte de revisão visa, em última análise, permitir a mudança da Constituição, adaptação da Constituição a novas necessidades, a novos impulsos, a novas forças, sem que para tanto seja preciso recorrer à revolução, sem que seja precido recorrer ao Poder Constituinte Originário".

No sistema da Constituição Federal Brasileira de 1988 o Poder Constituinte derivado se manifesta de duas formas absolutamente claras: i) reforma do texto constitucional, respeitando as limitações impostas pelo Constituinte originário por ocasião da elaboração da constituição; e ii) elaboração de constituição pelos Estados-membros integrantes da federação como corolário do princípio federativo. ${ }^{12}$

Dentro deste estudo da "teoria do poder constituinte", podemos ressaltar também o posicionamento de Jorge Reinaldo A. Vanossi que defende que existiria uma "terceira classe" de Poder Constituinte que seria o Poder Constituinte "revolucionário" que se contraporia ao Poder Constituinte originário na medida em que enquanto aquele não reconhece uma legalidade preexistente porque esta não existiu (seria a hipótese de independência e surgimentos de novos Estados, situação pouco usual mas que pode ainda ocorrer atualmente) enquanto o Poder Constituinte revolucionário não reconhece uma legalidade preexiste porque este poder revolucionário a derrubou.

\footnotetext{
${ }^{10}$ CARRIÓ, Genaro R.,Notas sobre Derecho y Lenguage. 4 ed., Buenos Aires: Editora: Abeledo Perrot, 1990. p. 245.

${ }^{11}$ DA SILVA, José Afonso, Curso de Direito Constitucional positivo, 35 ed. São Paulo. Editora: Malheiros, 2012. p. 65.

${ }^{12}$ CHIRADIA, Tatiana Del Giudice Cappa, A essência do Poder Constituinte. Dissertação de Mestrado PUC-SP, Orientador: Professor Doutor Antônio Carlos Mendes, São Paulo, 2009. p. 195.
} 
Por fim, importante ressaltar, que para o professor Jorge Reinaldo A. Vanossi ${ }^{13}$ existiria também uma terceira categoria de Poder Constituinte que ele denomina como sendo o "Poder Constituinte revolucionário".

Quanto esta suposta terceira categoria (visto que este entendimento não encontrou forte acolhida na doutrina constitucionalista) apontada por Vanossi devemos ressaltar que para Hans Kelsen ${ }^{14}$ a revolução ocorre quando a ordem jurídica é anulada ou substituída de forma ilegítima, instituindo uma nova ordem jurídica sem seguir os procedimentos previstos na ordem jurídica vigente para a sua modificação, ou seja, é o surgimento de forma ilegal fora do âmbito do direito, razão pela qual não poderia ser considerada como uma das espécies de manifestação do "Poder Constituinte".

Nesse passo, devemos reconhecer que um dos pressupostos necessários para que se tenha a exata compreensão das limitações constitucionais existentes ao poder de reforma constitucional (ou limitações ao poder constituinte derivado reformador e ao decorrente) é o estudo detalhado da concepção teórica do Poder Constituinte, inclusive, com o estudo detalhado do "Poder Constituinte originário".

\section{2 - Poder Constituinte Originário}

O Poder Constituinte originário do ponto de vista político é um poder supra legal sobre o qual todos os poderes constituídos (Poder Constituinte derivado) deverão guardar obediência após este efetuar a tarefa

\footnotetext{
${ }^{13}$ VANOSSI, Jorge Reinaldo A., Uma visão atualizada do Poder Constituinte. Revista de Direito Constitucional e ciência política, v. 4. p. 13.

${ }^{14}$ KELSEN, Hans, Teoria Geral do Direito e do Estado.Trad. por Luís Carlos Borges. 4 ed. São Paulo: Editora: Martins Fontes, 2005. p. 171.
} 
extrajurídica de criar a nova Constituição e por consequência inaugurar o ordenamento jurídico. ${ }^{15}$

Nesse tópico e também ao longo deste primeiro capítulo iremos analisar o "Poder Constituinte originário" com base nos ensinamentos que são tradicionalmente apontados pela doutrina constitucionalista, para que possamos perquirir quais são as características do Poder Constituinte originário, quais são aqueles que possuem legitimidade para estatuí-lo e quem é o detentor da titularidade deste poder (temas que se confundem pela própria natureza), quais são as formas de exercício do Poder Constituinte originário e quais são os limites para o seu exercício. Serão esses aspectos que serão abordados mais detidamente nos tópicos a seguir.

\subsection{1 - Características do Poder Constituinte Originário}

Os constitucionalistas enumeram diferentes características do Poder Constituinte originário. Iremos destacar algumas dessas características que são mais comumente citadas pela doutrina, sem pretender, contudo, esgotar o tema, haja vista que cada um dos autores identificam diferentes características do Poder Constituinte originário.

Preleciona o professor André Ramos Tavares que para Georges Burdeau $^{16}$ existem três características principais que qualificam este poder: i) ser um poder inicial, haja vista que inexiste outro acima dele; ii) ser um poder autônomo, pois, o titular detém a liberdade para decidir a ideia de direito que será criado; e iii) ser incondicionado, por não se submeter a qualquer tipo de regra e por não estar vinculado ao modelo constitucional anterior e nem qualquer tipo de forma jurídica preestabelecida.

Importante destacar que o professor Georges Burdeau ao elencar essas três características do Poder Constituinte originário criou uma linha

\footnotetext{
${ }^{15}$ BONAVIDES, Paulo, Curso de Direito Constitucional. 6 ed., São Paulo: Editora:Malheiros Editora LTDA., 1996. p.127.

${ }^{16}$ TAVARES, Andre Ramos. Curso de Direito Constitucional. São Paulo: Editora: Saraiva, 2002. p. 30.
} 
de pensamento que ficou conhecida como "teoria do direito autônomo", que se diferenciaria da Teoria do Direito Natural ou Jusnaturalismo (que preleciona que alguns direitos existem antes do surgimento do próprio Estado, logo o Poder Constituinte deveria respeitar esses direitos naturais preexistentes) e da Teoria do Direito Positivo (que entende que o direito surge apenas com o direito positivo criado pelo Estado).

Em linhas gerais este jurista defende a tese que o exercício do Poder Constituinte não guarda relação com o poder de fato (preexistente) e nem com o poder do direito (ordem jurídica criada pelo Estado).

Mais adiante, André Ramos Tavares ${ }^{17}$, cita o posicionamento de Genaro Carrió que reproduz uma série de expressões que são comumente dirigidas ao poder constituinte pelo sujeito que o descreve:

"Já Genaro Carrió ${ }^{18}$ vai alinhavar uma série de expressões ou feições em geral dirigidas ao poder constituinte por quem o descreve. Reproduz-se, doravante, o panorama jurídico esboçado por Carrió, que compreende o poder constituinte como: 1) inicial, autônomo e incondicionado; 2) por natureza insoburdinado (BURDEAU); 3) unitário, indivisível e absolutamente livre (SCHMITT); 4) aquele que, sendo de forma vaga e imprecisa, forma todas as formas (SCMITT); 5) a autoridade suprema, livre de toda formalidade, que se funda sobre si mesma e em si mesma (XIFRAS HERAS); 6) permanente e inalienável (XIFRAS HERAS); 7) tendo sua força vital e sua energia inesgotáveis (SCHMITT); 8) uma faculdade ilimitada e incontrolável (Imaz).

O professor Augusto Zimmermann entende que o poder constituinte se caracteriza por três características fundamentais ${ }^{19}$ : i) ser um poder inicial, pois, não extrai fundamento de nenhum outro poder anterior; ii) ser um poder ilimitado, haja vista, que não sofre quaisquer tipo de limitações ao direito positivo, ressaltando o autor, que para aqueles que seguem a corrente jusnaturalista, devem-se seguir aos preceitos estabelecidos pelo Direito

\footnotetext{
${ }^{17}$ TAVARES, Andre Ramos. Curso de Direito Constitucional. São Paulo: Editora: Saraiva, 2002. p. 31.

${ }^{18}$ CARRIÓ, Genaro R.,Notas sobre Derecho y Lenguage. 4 ed., Buenos Aires: Editora: Abeledo Perrot, 1990. p. 36.

${ }^{19}$ ZIMMERMANN, Augusto. Curso de Direito Constitucional. 3 ed. Rio de Janeiro: Editora Lumen Juris, 2004. p. 150
} 
Natural; e iii) ser um poder incondicionado, em razão de não possuir forma prefixada para a sua manifestação.

Podemos considerar que estas características do Poder Constituinte apresentadas pelo professor Augusto Zimmermann e por Georges Burdeau são aquelas apontadas mais comumente pela doutrina constitucionalista. Há ainda o posicionamento convergente do professor Gilmar Ferreira Mendes ${ }^{20}$ e do professor Alexandre de Moraes. ${ }^{21}$

Em tese de mestrado apresentada por Tatiana Chiradia ${ }^{22}$, a autora identificou as seguintes características do Poder Constituinte originário: i) ser um poder supremo; ii) ser um poder inicial; iii) ser um poder original; iv) ser um poder autônomo; v) ser um poder incondicionado; vi) ser um poder indivisível; vii) ser um poder ilimitado; e viii) ser um poder permanente.

A premissa que a autora chegou para defender a sua posição é de que o Poder Constituinte pertence a um mundo exterior ao direito, haja vista que este precede ao próprio direito. Por ocasião do estudo da fenomenologia do procedimento constituinte, se aproxima desta tese também o professor Gomes Canotilho ${ }^{23}$ :

“ O desencadeamento de procedimentos constituintes tendentes à elaboração de constituições anda geralmente associado a momentos constitucionais extraordinários: (revolução, nascimento de novos estados, transições constitucionais, golpes de Estado, "queda de muros"). Nestes factos complexos, situados ainda a montante do procedimento constituinte propriamente dito, vão geralmente implícita "decisões" de natureza pré-constituinte. Estas decisões geralmente implícitas reconduzem-se em geral a dois tipos: (1) decisão política de elaborar uma lei fundamental - constituição; (2) edição de leis constitucionais provisórias destinadas a dar uma primeira forma jurídica ao "novo estado de coisas" e a definir as linhas orientadoras (procedimento constituinte propriamente dito)."

\footnotetext{
${ }^{20}$ MENDES, Gilmar Ferreira \& BRANCO, Paulo Gustavo Gonet. Curso de Direito Constitucional. 8 ed. revisada e atualizada. São Paulo: Editora: Saraiva, 2013. p. 104.

${ }^{21}$ MORAES, Alexandre de, Direito Constitucional. 21 ed. São Paulo: Editora: Atlas, 2007. p. 23.

${ }^{22}$ CHIRADIA, Tatiana Del Giudice Cappa, A essência do Poder Constituinte. Dissertação de Mestrado PUC-SP, Orientador: Professor Doutor Antônio Carlos Mendes, São Paulo, 2009. p. 176.

${ }^{23}$ CANOTILHO, José Joaquim Gomes. Direito Constitucional e Teoria da Constituição. 7 ed.

Coimbra: Editora: Livraria Almedina, 2003. p. 71.
} 
Nessa toada, destacando as características defendidas pela autora, o Poder Constituinte originário, seria um "poder supremo", pois, o fruto da sua obra, a própria Constituição, é um poder superior a todas as demais normas legais que por sua vez deverão guardar respeito e extrair o seu fundamento de validade dela.

Seguindo a linha de exposição teórica apresentada pela autora o Poder Constituinte originário seria um "poder inicial", pois, ele inaugura a ordem jurídica do Estado, sem observar qualquer tipo de direito anterior, devendo apenas respeitar o direito natural para aqueles autores que são adeptos da corrente jusnaturalista.

O Poder Constituinte originário, de igual modo, é um poder dotado de originalidade, na medida em que institucionaliza por sua vontade um novo Estado através da Constituição que fora criada.

Outra característica do Poder Constituinte originário é de que ele é um "poder autônomo", haja vista que depende apenas de si próprio para a instauração de uma nova ordem jurídica do Estado, não estando vinculado a ratificação ou anuência de qualquer outro tipo de Poder ou órgão estatal.

O Poder Constituinte originário é um "poder incondicionado", na medida em que, ao ser criado não está obrigado a adotar nenhuma forma prefixada anteriormente ou a qualquer tipo de ritual constitucional adotado historicamente por determinado Estado, podendo, portanto, o titular deste Poder Constituinte adotar a forma que julgar mais adequada para exercer este poder.

Ao ser criada uma nova constituição o Poder Constituinte originário é absolutamente livre para criar a nova ordem jurídica, sendo este poder uno, indivisível, não podendo ser repartido de qualquer modo. 
Alguns autores defendem a tese de que o Poder Constituinte seria um poder "que tudo pode", nesse sentido seria um "poder absolutamente ilimitado" que não está vinculado a qualquer tipo de parâmetro estabelecido pela ordem jurídica anterior de determinado Estado nem por critérios comumente estabelecidos por outras Cartas Constitucionais.

Para os defensores deste "poder ilimitado" do Poder Constituinte é fundamental a defesa desta característica, haja vista que se o titular do Poder Constituinte exerceu este poder para alterar de forma radical o ordenamento jurídico seja através de uma revolução (que para boa parte da doutrina constitucionalista é juridicamente considerado como um meio ilegítimo para o exercício do Poder Constituinte originário), seja através de um meio legítimo, entendeu por bem que a ordem jurídica não deveria ser mantida, é absolutamente natural que não esteja sujeita a limitações impostas ao direito suprimido, porque senão em última análise isso inviabilizaria a própria noção de Poder Constituinte, impedindo, por conseguinte, a elaboração de uma nova Constituição.

Quanto a este ponto específico, devemos ressaltar que existe uma divergência de entendimento entre a corrente positivista e a corrente jusnaturalista, haja vista que para os defensores desta última, o Poder Constituinte originário obrigatoriamente deveria respeitar os direitos naturais do homem, os direitos fundamentais, sendo vedado o "direito ao retrocesso".

Por fim, destaca a autora que o poder constituinte originário seria um "poder permanente", pois, mesmo após de encerrado (após a edição e entrada em vigor da nova Constituição que está no topo da ordem jurídica do Estado) este poder subsiste forte com a possibilidade, inclusive, de se manifestar novamente através da edição de uma nova Constituição quando o titular do Poder Constituinte originário (o “povo”) julgar necessário. 


\title{
1.2.2 - A Legitimidade e a Titularidade do Poder Constituinte Originário
}

A legitimidade e a titularidade do "Poder Constituinte" é um dos temas mais polêmicos que envolvem o direito constitucional.

A "Teoria do poder Constituinte" que foi melhor descrita na obra "O que é o terceiro Estado?", de Sieyés, utilizou como critério para que fosse auferida a legitimidade ou não do poder constituinte seria a identidade entre a "nação" e "Poder Constituinte originário", bem como na capacidade desta se autogovernar e também para ter seus próprios representantes.

O professor Paulo Bonavides ${ }^{24}$ utilizando-se do magistério de Paul Bastid (Le Instituions Politiques de la Monarchie Parlamentaire Française, Paris, 1954, p. 164) aborda do ponto de vista político acerca da existência da legitimidade e da titularidade do Poder Constituinte, senão vejamos:

\begin{abstract}
“(...) Um constitucionalista da Restauração Francesa - Béranger - encarava também a titularidade do poder constituinte como uma questão de fato. A inquirição sobre a pessoa a quem esse poder havia de pertencer recebera dele, conforme adverte Paul Bastid, uma crua resposta: a quem tiver o poder de agarrá-lo. Sendo um poder emergencial, 'um poder que aparece com as crises e com elas desaparece', vem ele coberto de pessimismo nas reflexões do restaurador. Agitar esse problema - o de saber ou determinar qual o titular de semelhante poder - afigura-se-lhe temerário, conforme ressalta Bastid, pois 'o poder constituinte tem algo de misterioso, sendo imprudente inquirir-lhe a origem".

(grifos nossos)
\end{abstract}

Do posicionamento acima transcrito, podemos desde já ressaltar um relevante dado acerca da titularidade do Poder Constituinte originário: ele é um poder que "pertence a quem tem a capacidade de agarrá-lo". Partindo-se de uma premissa apenas política do Poder Constituinte originário notamos que justamente por possuir esse caráter "extrajurídico", "ilimitado" e "incondicionado", em última análise aquele que assumir o poder político e for capaz de efetuar as alterações no ordenamento jurídico através da edição

\footnotetext{
${ }^{24}$ BONAVIDES, Paulo, Curso de Direito Constitucional. 6 ed., São Paulo: Editora:Malheiros Editora LTDA., 1996. p.125.
} 
da nova Carta Constitucional será o titular de fato do Poder Constituinte. Outra questão de maior relevo e que a doutrina constitucionalista e também os pensadores da ciência política se debruçaram a discutir se esta ordem jurídica instaurada será necessariamente "legítima". Como é possível intuir a questão atinente à legitimidade do Poder Constituinte originário está extremamente vinculada ao titular do exercício deste poder (se pertence ao povo ou a nação ou a algum tipo de tirando, ditador, dentre outros afins).

Com efeito, nos socorremos do magistério de Dalmo de Abreu Dallari $^{25}$ que com a autoridade e a didática que lhe é peculiar, discorre acerca da legitimidade da Constituição e do próprio Poder Constituinte, constatando, que este tema foi esteve em maior evidência a partir da segunda metade do século XIX, quando naquela ocasião movimentos operários na Europa utilizaram a Constituição como lógica argumentativa para reivindicar os seus direitos que não eram respeitados pelos governantes e também pelos empregadores.

Por conta destas reivindicações, no ano de 1863 (para Konrad $\mathrm{Hesse}^{26}$ a citada conferência teria ocorrido em 16 de abril de 1862 numa Associação Liberal-Progressista), foi proferida por Ferdinand Lassalle a famosa conferência proferida tanto para intelectuais como para os operários da época e que tinha como tema desta conferência a dissertação acerca da "A essência da Constituição"27, que tinha uma finalidade mais política do que jurídica para instruir os operários em suas lutas, mas que no final das contas acabou por gerar grande impacto na doutrina constitucionalista ao efetuar a distinção entre a "constituição real" e a "constituição efetiva" (aquela que era aplicada na prática com base na força política dos detentores circunstanciais do poder político), diferenciando-se da

\footnotetext{
${ }^{25}$ DALLARI, Dalmo de Abreu, A constituição na vida dos povos: da Idade Média ao século XXI. São Paulo: Editora: Saraiva, 2010. p. 302.

${ }^{26}$ HESS, Konrad, A Força Normativa da Constituição. Tradução: Gilmar Ferreira Mendes, Porto Alegre, Editora: Sergio Antonio Fabris, 1991. p. 9.

${ }^{27}$ LASSALE, Ferdinand, Discours et pamphlets - De l' essence d'une Constituion. Paris: Giard Briére, 1903.
} 
"constituição escrita num pedaço de papel" que poderia ser ou não aplicada. A simples defesa desta teoria foi inovadora naquele período histórico por reconhecer um elemento sociológico e extrajurídico que influencia de forma clara o ordenamento jurídico.

Naquela oportunidade Lassalle afirmou expressamente que os problemas constitucionais não seriam problemas propriamente de direito, mas sim, problemas que envolveriam o exercício do poder. $\mathrm{O}$ autor considerava que a "Constituição verdadeira" de uma país somente existiria de acordo com os fatores reais do poder independentemente da existência de Constituições jurídicas escritas (que para o autor teria valor apenas enquanto estivesse de acordo com a "Constituição verdadeira").

Esta concepção teórica considerava a Constituição como fruto das diversas forças existentes na sociedade, e para tanto o autor citou alguns exemplos de forças políticas e muitas vezes com interesses antagônicos que existiriam no seio da sociedade, tais como: i) a monarquia; ii) a aristocracia; iii) a grande burguesia; iv) os banqueiros e; v) a pequena burguesia e a

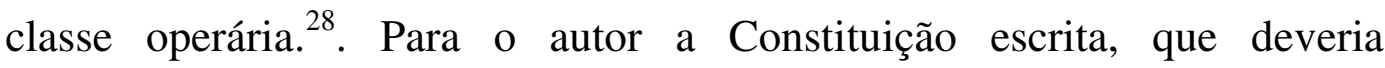
considerar o interesse de todos esses diferentes grupos, só vigeria enquanto a "constituição real" estivesse do ponto de vista político exprimindo o interesse de todos esses grupos, tal como previsto na Constituição, salvo contrário prevaleceria a "constituição real".

Com base nessa linha de raciocínio, podemos considerar que certamente dentro do que era albergado no âmbito do "direito" não se enquadrava como "direito" as reivindicações efetuadas pelos operários com fundamento na Constituição.

Com base na tese acima transcrita, podemos interpretar, ao levar esta linha de raciocínio até as últimas consequências, que inexistiria motivo para

\footnotetext{
${ }^{28}$ Essas referências foram observadas por AGUIAR VIEIRA, Yacir de, A essência da Constituição no pensamento de Lassale e de Konrad Hesse. Brasília a, 35, n.139 jul./set. 1998. p. 74-75.
} 
discutir a legitimidade da Constituição e por consequência do próprio Poder Constituinte originário, haja vista que no final das contas a Constituição não passaria de um "mero pedaço de papel" e que não possuiria força vinculante para os cidadãos e para os Estados.

Entretanto, importante ressaltar, que ao efetuar essa diferenciação entre a "Constituição escrita" e a "Constituição real", Ferdinand de Lassale não tinha como objetivo negar o direito dos operários que porventura estivessem protegidos na Carta Constitucional, mas apenas queria chamar a atenção deles para que na realidade prática as forças políticas dominantes poderiam desconsiderar todos esses direitos e agirem da forma que melhor lhe aprouvesse, razão pela qual nessa oportunidade caberia ao proletário e a pequena burguesia se organizar de forma a lutar e a garantir os seus direitos.

Noutro giro, nos utilizamos das palavras que foram destacadas por Rudolph Von Jhering ${ }^{29}$ : “o direito no seu movimento histórico apresentanos pois um quadro de lucubrações, de combates, de lutas, numa palavra de penosos esforços".

Pois bem, a interpretação "sociológica" apresentada por Ferdinand de Lassale foi no plano acadêmico aperfeiçoada (em outro momento histórico completamente distinto) pelo jurista Konrad Hesse que considerava que a "Constituição escrita" não seria apenas um "simples pedaço de papel", incapaz de conter a "Constituição real" representada pelas forças políticas de determinada sociedade. $\mathrm{O}$ autor defendeu que o Direito Constitucional não está em contraponto com a natureza da Constituição, ou seja, a "Constituição jurídica" não necessariamente sucumbirá diante da "Constituição real", pois, ela mesmo prevê mecanismos para organização das crises constitucionais. Se porventura, como a história assim o ensina, prevalecer as forças políticas a conclusão

\footnotetext{
${ }^{29}$ VON JHERING, Rudolf, A luta pelo Direito. Tradução João de Vasconcelos, Rio de Janeiro: Editora: Forense, 1972. p.31.
} 
inexorável é de que será criada uma nova Carta Constitucional que será dotada igualmente de eficácia jurídica e que preverá a forma de se lidar com os conflitos constitucionais de acordo com a vontade do legislador constituinte originário.

Com efeito, o autor ${ }^{30}$ ressalta que a pretensão de eficácia das normas constitucionais faz com que a realidade social e a política deve ser conformada com a Constituição. Ademais, a possibilidade da Constituição impor tarefas aos cidadãos e aos Estados a transformaria numa força ativa o que implicaria no afastamento da tese da Lassalle $^{31}$, na medida que o respeito à Constituição não está subordinado aos interesses imediatos da autoridade política.

A importância do estudo dessas duas diferentes teses antagônicas, influi diretamente na importância do conceito da legitimidade do Poder Constituinte, haja vista que a própria concepção de Constituição é que "está em jogo".

Com efeito, apenas quando a Constituição possui eficácia jurídica e apenas quando suas normas são plenamente aplicáveis, independentemente dos "fatores reais do poder" é que haverá a necessária previsibilidade do ordenamento jurídico. Nesse caso, como este é o entendimento que prevalece com ampla maioria na doutrina constitucionalista, torna-se ainda mais relevante o estudo teórico acerca de quem é o "detentor" da titularidade deste Poder Constituinte para que possamos definir quando a nova ordem jurídica imposta é "legítima" ou "ilegítima".

Nesse diapasão, é forçoso reconhecer, conforme descrito por Konrad Hesse $^{32}$, que em diversos momentos a Constituição em vigor de determinado Estado, a denominada "constituição jurídica", pode não

\footnotetext{
${ }^{30}$ HESS, Konrad, A Força Normativa da Constituição, tradução: Gilmar Ferreira Mendes, Porto Alegre, Editora: Sergio Antonio Fabris, 1991.

${ }^{31}$ LASSALE, Ferdinand, Discours et pamphlets - De l' essence d'une Constituion. Paris: Giard Briére, 1903.

${ }^{32}$ HESS, Konrad. Op. cit., p. 25.
} 
refletir mais os anseios da sociedade que a instituiu, não oferecendo, portanto mecanismos jurídicos para garantia da felicidade e do bem-estar de um povo. Ou seja, as normas jurídicas que ela prescreve não estão mais em conformidade com a vida de determinada sociedade. Nesse caso, pode ocorrer que nesses casos de gravidade institucional, a Constituição jurídica sucumba diante da "constituição real" (forças políticas existentes no seio da comunidade), gerando um Poder Constituinte originário que ficará encarregado de criar uma nova Constituição que se adeque aos anseios daquela determinada sociedade.

Por outro turno, ainda que a Constituição reflita os anseios e corresponda aos interesses mais nobres de determinada população, uma revolução ou um golpe de estado podem encerrar a ordem jurídica vigente e instaurar outra que esteja de acordo com os ideais daqueles que assumiram o poder, como infelizmente ocorreu no âmbito do Brasil em diversos momentos na nossa história institucional.

Importante ressaltar, que mesmo que o "Poder Constituinte" não seja legítimo ele busca fundamentar-se numa "suposta legalidade" a fim de "legitimar" sob o prisma político todos os seus atos. No Brasil no golpe militar de 1964 a sua suposta "legitimidade" estava contida no Ato Institucional de 9 de abril de 1964 que foi feito para vigorar até 31 de janeiro de $1966 .^{33}$, que manteve formalmente a Constituição democrática de 1946 e que só foi revogada com a edição da Constituição de 1967 e com a "Constituição" de 1969 (assim denominada pela maior parte da doutrina constitucionalista apesar de formalmente ter se apresentado como emenda constitucional).

Nessa toada, à luz do que foi acima exposto é tema de maior relevância o estudo acerca da legitimidade e da titularidade do Poder

\footnotetext{
${ }^{33}$ BONAVIDES, Paulo, Curso de Direito Constitucional. 6 ed., São Paulo: Editora:Malheiros Editora LTDA., 1996. p.143.
} 
Constituinte, até para que seja possível perquirir do ponto de vista político acerca da "justiça” do ordenamento jurídico de determinado Estado.

Para melhor delimitar o tema, devemos definir o que seria de fato a titularidade ou a legitimidade para o exercício do Poder Constituinte. Do ponto de vista prático, conforme observado pelo professor Gomes Canotilho $^{34}$, o detentor é aquele que na prática possui o poder político para instituir a Lei Fundamental (a Constituição) de forma pura e simples.

Numa abordagem histórica, a titularidade do Poder Constituinte originário estava vinculada diretamente à Deus e aos seus representantes legais na Terra, ou seja, os reis que detinham todo o poder político e poderiam alterar a constituição, ao menos em tese, ao seu livre alvitre.

Conforme preleciona o professor Paulo Bonavides ${ }^{35}$ esta titularidade do Poder Constituinte foi passada na Idade Média ao príncipe ou ao monarca que seria o representante legal de Deus na Terra.

Esse entendimento foi alterado graças à influência de Sieyés, que para muitos é considerado como o criador da "Teoria do Poder Constituinte" ${ }^{36}$ e que foi o autor do célebre livro: "Qu'est-ce que le TiersEtat".

Na sua obra, Sieyés efetua a diferenciação entre o poder constituinte e os poderes constituídos. Para tanto, fundamenta a sua teoria do Poder Constituinte em que qualifica a "nação" como a detentora real deste poder, a "nação" que estudos posteriores indicam que na época se confundia com a burguesia, com o terceiro estado, que exercia no entendimento do autor na prática todas as principais funções da comunidade nacional, mas,

\footnotetext{
${ }^{34}$ CANOTILHO, José Joaquim Gomes. Direito Constitucional e Teoria da Constituição. 7 ed. Coimbra: Editora: Livraria Almedina, 2003. p. 65.

${ }^{35}$ BONAVIDES, Paulo, Curso de Direito Constitucional. 6 ed., São Paulo: Editora:Malheiros Editora LTDA., 1996. p. 136.

${ }^{36}$ ZIMMERMANN, Augusto. Curso de Direito Constitucional. 3 ed. Rio de Janeiro: Editora Lumen Juris, 2004. p. 143.
} 
entretanto, não tinham nenhuma representação e influência política real em face do clero e da nobreza ${ }^{37}$.

As "exigências" que eram efetuadas pelo terceiro estado (a nação), eram as seguintes: i) a eleição dos representantes por eleitores do seu estamento social; ii) que o número de deputados da "nação" fossem em número igual aos da nobreza e do clero; e iii) que a votação dos Estados Gerais deveria ser por cabeça (número de membros) e não por estamentos, pois, assim impediria que o clero e a nobreza se unissem sempre contra o terceiro estado.

A concepção de Sieyés acerca do "pouvoir constituant", que decorre no entender do teórico da soberania constituinte do povo (ou da nação) se manifesta também como luta ao poder absolutista monárquico e possui dois momentos fundamentais, conforme preleciona o professor J.J. Gomes Canotilho $^{38}$ :

“(...) em Sieyés a fórmula pouvoir constituant surge estreitamente associada à luta contra a monarquia absoluta.

Os momentos fundamentais da teoria do poder constituinte de Sieiyés são os seguintes: (1) recorte de um poder constituinte de nação entendido como poder originário e soberano; (2) plena liberdade da nacão para criar uma constituição, pois a nação ao 'fazer uma obra constituinte', não está sujeita a formas, limites ou condicões preexistentes. Os autores modernos salientam que, no fundo, a teoria do poder constituinte de Sieyéis é, simultaneamente, desconstituinte e reconstituinte. O poder constituinte antes de ser constituinte é desconstituinte porque dirigido contra a 'forma monárquica' ou 'poder constituído pela monarquia'. Uma vez abolido o poder monárquico, impõe-se uma 'reorgarnização', um dar 'forma', uma reconstrução de ordem jurídicopolítica. O poder constituinte da Nação entende-se agora como poder constituinte informado pela ideia criadora e projectante da instauração de uma nova ordem jurídica plasmada numa constituição. Os poderes conformados e regulados por esta constituição criada pelo poder constituinte (inclusive o poder de rever ou emendar à constituição - poder de revisão) seriam poderes constituídos." (grifos nossos)

\footnotetext{
${ }^{37}$ ZIMMERMANN, Augusto. Curso de Direito Constitucional. 3 ed. Rio de Janeiro: Editora Lumen Juris, 2004. p. 145.

${ }^{38}$ CANOTILHO, José Joaquim Gomes. Direito Constitucional e Teoria da Constituição. 7 ed. Coimbra: Editora: Livraria Almedina, 2003. p. 65.
} 
É válida transcrever a importância que o Siéyés dá ao conceito de nação, pois, para ele "a nação existe antes de tudo, ela é a origem de tudo. Sua vontade é sempre legal, ela é a própria lei”.39

Para Jorge Reinaldo A. Vanossi ${ }^{40}$, é a partir de Siéyés que surge a noção de "função" do Poder Constituinte. Com a ideia de separação de poderes, que surgiu na origem do constitucionalismo e também do Racionalismo, só é possível efetuar esta separação de poderes com um "poder superior", capaz de levar a cabo essa distribuição de poderes. Esse "poder superior" é justamente o poder constituinte a qual os poderes constituídos devem guardar obediência, ou seja, explicando de forma mais simples: o Poder Constituinte originário seria necessário para a garantia das separações dos poderes.

Após a difusão da teoria acima exposta, podemos afirmar que grande parte da doutrina constitucionalista contemporânea considera o povo como o real titular do poder constituinte originário. Nesse sentido, dentre outros, expressamente se manifestam nesse sentido: André Ramos Tavares ${ }^{41}$, Tatiana Chiradia $^{42}$, Augusto Zimmermann (que ressalta que na prática ele só consegue se manifestar nas sociedades democráticas) ${ }^{43}$, Alexandre de Moraes $^{44}$, e no âmbito do direito lusitano o jurista português Gomes Canotilho. $^{45}$

\footnotetext{
${ }^{39}$ SYÉYÉS, Emmanuel, Qu'est-ce que le Tiers Etat?. França, Quadrige/Presses Universitaires de France, 1982.p.67.

${ }^{40}$ VANOSSI, Jorge Reinaldo A., Uma visão atualizada do Poder Constituinte.Revista de Direito Constitucional e ciência política. v. 4. p. 11.

${ }^{41}$ TAVARES, Andre Ramos. Curso de Direito Constitucional. São Paulo: Editora: Saraiva, 2002. p. 54.

${ }^{42}$ CHIRADIA, Tatiana Del Giudice Cappa, A essência do Poder Constituinte. Dissertação de Mestrado PUC-SP, Orientador: Professor Doutor Antônio Carlos Mendes, São Paulo, 2009. p. 191.

${ }^{43}$ ZIMMERMANN, Augusto. Curso de Direito Constitucional. 3 ed. Rio de Janeiro: Editora Lumen Juris, 2004. p. 149.

${ }^{44}$ MORAES, Alexandre de, Direito Constitucional. 21 ed . São Paulo: Editora: Atlas, 2007. p. 21.

${ }^{45}$ CANOTILHO, José Joaquim Gomes. Direito Constitucional e Teoria da Constituição. 7 ed.

Coimbra: Editora: Livraria Almedina. p. 69.
} 
Importante ressaltar que, dentre outros autores, Gomes Canotilho também critica o conceito de "nação" adotado por Siéyes por reputá-lo excessivamente subjetivo.

\begin{abstract}
"Ao fala-se de povo político como titular do poder constituinte e de povo como "grandeza pluralística" pretende-se também insinuar o abandono de um mito que acompanhou quase sempre a teoria da titularidade do poder constituinte: o mito da subjetividade originária (povo, nação, Estado). Se se quiser encontrar um sujeito para este poder teremos de localizar naquele complexo de forças políticas plurais - e daí a plurisubjectividade do poder constituinte - capazer de definir, propor e defender ideias, padrões de conduta e modelos organizativos, susceptíveis de servir de base à constituição jurídico formal".

(grifos nossos)
\end{abstract}

Por sua vez o jurista italiano Antonio Negri ${ }^{46}$, também entende que o conceito de "nação", não é bom o suficiente para qualificação da titularidade do poder constituinte, preferindo o autor a adoção do conceito de "multidão revolucionária":

"Primeira hipótese: o sujeito em ato é a nação. À primeira vista, este conceito pareceria singularmente adequado àquele de procedimento absoluto, não fosse o fato de que ele é um conceito genérico, real só na imaginação (e, portanto, indefinidamente manipulável). Por outro lado, porém, é um conceito historicamente determinado, frequentemente em função da ruptura do processo constituinte, de sua hipótese ou limitação. A primeira acepção de nação (que resulta um intrincado jogo que envolve determinismo ético, valorações históricas, necessidades políticas, urgências jurídicas, mas sobretudo uma forte sobredeterminação naturalista) produz uma polissemia que abre a possibilidade de resultados sofísticos para o conceito, e de um destino instrumental para a sua prática."

(grifos nossos)

Seguindo a teoria constitucional predominante, entendemos que a titularidade e a legitimidade do Poder Constituinte não pertença à "nação", mas sim ao "povo político", conforme preleciona o professor português Gomes Canotilho, haja vista que aquele conceito é excessivamente vago e como bem salientado por Antonio Negri "só existe na imaginação daquele que o caracteriza”.

\footnotetext{
${ }^{46}$ NEGRI, Antonio. O poder constituinte: ensaio sobre alternativas da modernidade, traduação Adriano Pilatti. Rio de Janeiro: Editora DPeA, 2002. p. 42-43.
} 
O professor Gomes Canotilho ${ }^{47}$ também afasta do conceito de titular do Poder Constituinte o conceito naturalista, étnico ou de raça. De igual modo, os revolucionários que representam apenas uma pequena parcela da população, mas que chegam ao poder (seja da classe do proletário ou defensores de um nacionalismo exagerado ou o fascismo, por exemplo) não seriam considerados titulares do Poder Constituinte, ainda que eventualmente chegassem ao poder e conseguissem efetuar a criação de um novo texto constitucional.

Ainda que na prática esses "revolucionários" inovassem a ordem jurídica e nesse sentido fossem os "titulares de fato do Poder Constituinte originário", com a criação de uma nova Constituição, eles não seriam os titulares "legítimos" e não se confundiriam com o "povo político", ainda que alegassem que estariam agindo em seu nome.

O posicionamento destacado ao longo do presente tópico nos faz crer que o detentor legítimo é o "povo real" e não aquelas "parcelas minoritárias da sociedade" que circunstancialmente assumam o poder afirmando que representam o povo mas que na prática representam apenas aqueles que defendem a sua ideologia.

Quanto a este aspecto da legitimidade do Poder Constituinte originário que ora tentamos explicitar, devemos destacar as preciosas lições do professor Gilmar Ferreira Mendes ${ }^{48}$ que assim aborda o tema:

\footnotetext{
"Por isso, um grupo que se arrogue a condição de representante do poder constituinte originário, se se dispuser a redigir uma Constituição que hostilize esses valores dominantes, não haverá de obter o acolhimento de suas regras pela população, não terá êxito no seu empreendimento revolucionário e não será reconhecido como poder constituinte originário. Afinal, só é dado falar em atuação do poder constituinte originário se o grupo que diz representa-lo colher a anuência do povo, ou seja, se vir ratificada a sua invocada representação popular. Do contrário, estará havendo apenas uma insurreição, a ser sancionada como delito penal. Quem tenta romper com a ordem constitucional para instaurar outra
}

\footnotetext{
${ }^{47}$ CANOTILHO, José Joaquim Gomes. Direito Constitucional e Teoria da Constituição. 7 ed. Coimbra: Editora: Livraria Almedina. p. 69.

${ }^{48}$ MENDES, Gilmar Ferreira \& BRANCO, Paulo Gustavo Gonet. Curso de Direito Constitucional. 8 ed. revisada e atualizada. São Paulo: Editora: Saraiva, 2013. p.105.
} 
e não obtém a adesão dos cidadãos não exerce poder constituinte originário, mas age como rebelde criminoso".

Nesse sentido, importante ressaltar, que o "povo político" para o professor Gomes Canotilho não guarda relação com a ideia de representantes eleitos, que ele denomina como "povo activo" que atuam por "consentimento tácito". De igual modo, o conceito de "povo político" para fins de conceituação de titulares do Poder Constituinte originário também não se confundem com o "corpo eleito" (cidadão - vínculo da cidadania que se manifesta pelo exercício do direitos políticos). Ou seja, apenas o "povo real" é o legítimo titular do Poder Constituinte originário:

"Em conclusão: só o povo real - concebido como comunidade aberta de sujeitos constituintes que entre si 'contratualizam', 'pactuam' e consentem o modo de governo da cidade -, tem o poder de disposição e conformação da ordem político e social".

A identidade entre "povo" e "Poder Constituinte originário" não é hegemônica na doutrina. Muito pelo contrário, vozes relevantes como a do jurista italiano Antonio $\mathrm{Negri}^{49}$, um dos principais estudiosos sobre o tema, critica igualmente esta posição, por reputar excessivamente abstrata:

"Uma segunda hipótese de adequação entre sujeito e estrutura, em sentido dinâmico, é proposta quando o sujeito é caracterizado como povo. Contudo, o conceito de povo não é menos genérico que o de nação: também esta definição é rapidamente aprisionada pelo mecanismo jurídico de qualificação. Sobre a essência genérica do conceito, aplica-se a leitura constitucional: se o povo é sujeito do poder constituinte somente pode sê-lo na medida em que se submete a uma organização preliminar capaz de exprimir sua essência. De fato, seria uma contradição em termos imaginar, e sobretudo, assumir como sujeito científico 'uma força ordenadora que pode ser ordenada por uma multidão sem ordem'. Aqui, são superados os limites e preconceitos naturalistas e organizicistas que se manifestam na concepção de poder constituinte como atributo da nação: a vontade teórica de romper com as ambiguidades do conceito de nação é nítida. Entretanto, é igualmente nítida a vontade de neutralizar a força expansiva do poder constituinte. Não é casual, antes representa uma necessidade, o fato de que toda a definição do sujeito constituinte em termos de povo acabe em normativismo, em exaltação do direito constituído. Tal definição confunde o poder constituinte com uma das fontes internas do direito, com as dinâmicas de sua revisão, de sua renovação constitucional. Em síntese, o poder constituinte é povo nas dimensões de representação e somente nestas ".

\footnotetext{
${ }^{49}$ NEGRI, Antonio. O poder constituinte: ensaio sobre alternativas da modernidade, traduação Adriano Pilatti. Rio de Janeiro: Editora DPeA, 2002. p. 43-44.
} 
Em linhas gerais, de modo pouco usual, o jurista italiano entende que o constitucionalismo limita o real conceito e a potência verdadeira do Poder Constituinte, razão pela qual, entende, após efetuar uma análise teórica e prática das revoluções modernas (revolução inglesa, italiana, americana, francesa e russa) entende que o real titular do poder constituinte é a "multidão" revolucionária que é a única de efetuar as reais transformações da sociedade. ${ }^{50}$

\subsection{3 - Formas de Exercício do Poder Constituinte Originário}

A doutrina costuma elencar os principais modos pelos quais comumente é exercido o Poder Constituinte originário.

Para o professor Augusto Zimmermann ${ }^{51}$ o exercício do Poder Constituinte originário é dividido em duas formas: a forma democrática e a forma não democrática.

Com efeito, entende o professor, que a forma mais clara de violação da democracia é quando o próprio governante, detentor do poder político de determinada sociedade, outorga a constituição, sem que o povo tenha participado do processo de elaboração de normas constitucionais.

O titular do Poder Constituinte originário em última análise é o "povo político", entretanto, os "fatores reais de poder" de determinada sociedade podem ocasionar que na prática o Poder Constituinte originário, apesar de ser titularidade do povo, possa ser exercido de forma não democrática por um único governante, por um ditador, por uma elite aristocrática, dentre outros formas não democráticas que ao longo da história surgiram.

\footnotetext{
${ }^{50}$ Para um maior aprofundamento da teoria abordada pelo jurista Antonio Negri, consultar a dissertação de mestrado: GUIMARAENS, Francisco De. O poder constituinte no conceito de Antonio Negri - Um conceito muito além da Modernidade hegemônica/ orientador: Carlos Alberto Plastino, Co-Orientador: Adriano Pilatti - Rio de Janeiro, Departamento de Direito, 2002. p. 173.

${ }^{51}$ ZIMMERMANN, Augusto. Curso de Direito Constitucional. 3 ed. Rio de Janeiro: Editora Lumen Juris, 2004. p. 151
} 
Por outro turno, ressalta o autor que o exercício do Poder Constituinte originário pode surgir de forma democrática (que felizmente é o modelo que atualmente vige na Constituição Brasileira de 1988), podemos observar que na sociedade internacional, com o avançar do tempo e com o surgimento de uma verdadeira "consciência constitucional" no seio das sociedades (que repudiam de forma cada vez mais veemente as formas não democráticas de governo), prevalecem o exercício da participação popular, sendo a forma mais usual através dos mandatários eleitos democraticamente pelo povo, que se reúnem através de uma Assembleia Constituinte que tem por objetivo elaborar um novo texto constitucional.

Por fim, existe um modelo misto que ocorreria na hipótese do povo ser consultado, através de plebiscito, acerca da possibilidade de fazer um único homem responsável pela elaboração da Constituição. Nesse caso, o detentor da titularidade do Poder Constituinte originário transmitiria o seu exercício a outra pessoa, normalmente o "soberano", "ditador", etç. Esse método também é conhecido como método "Bonapartista" ou "Cesarista",52.

Já para o professor Alexandre de Moraes $^{53}$ o exercício do Poder Constituinte pode se expressas basicamente por duas formas: i) através da outorga; e ii) através da Assembleia Nacional Constituinte ou por convenção.

No entendimento do citado professor, a outorga ocorreria quando a Constituição é declarada unilateralmente pelo agente revolucionário, que autolimitaria o seu poder, tal como foi, por exemplo, a Constituição Brasileira de 1824, a de 1937 (também conhecida como a "Constituição polaca", em razão da similitude com a Constituição da Polônia, utilizada como modelo e que não era democrática) e o Ato institucional n. 1 de 1964 (que na prática deu forma jurídica ao golpe militar ocorrido no ano de 1964 limitando os efeitos da Constituição democrática de 1946). Outros

\footnotetext{
${ }^{52}$ DA SILVA, José Afonso, Curso de Direito Constitucional positivo, 35 ed. São Paulo. Editora: Malheiros, 2012. p. 42.

${ }^{53}$ MORAES, Alexandre de, Direito Constitucional. 21 ed . São Paulo: Editora: Atlas, 2007. p. 23.
} 
exemplos claros de constituições outorgadas na histórias constitucional brasileira foram as Constituições de 1967 e a sua Emenda n. 1 (a Constituição de 1969), ambas impostas pelo regime militar e restringiram os direitos individuais.

Para o professor José Afonso da Silva ${ }^{54}$, o exercício do Poder Constituinte originário pode ocorrer mediante outorga sempre que o governante elaborasse a Constituição e a instituísse sem a participação popular seja na sua pessoa (do ditador, monarca, presidente, junta governativa) ou através de interposta pessoa (nesse ponto, ao considerar a possiblidade de delegação para um grupo maior de pessoas, a conceituação do mestre da USP é mais abrangente que o elaborada pelo professor Alexandre de Moraes).

O segundo modelo de exercício do Poder Constituinte originário descrito pelo professor Alexandre de Moraes ocorre quando o Poder Constituinte originário é exercido através da Assembleia Nacional Constituinte, que também pode ser denominada de convenção, quando os representante populares, são convocados pelos "agentes revolucionários" (não concordamos com esta expressão adotada pelo renomado professor, entendemos que o mais adequado seria pelo "povo" ou "legislador constituinte originário representado pelos detentores do sufrágio político") para estabelecer o texto constitucional, tal como foi na história constitucional brasileira nas Constituições de: 1891, 1934, 1946, 1967 e 1988).

Seguindo ainda no estudo da doutrina constitucionalista nacional acerca do exercício do Poder Constituinte originário, importante ressaltar o posicionamento defendido pelo professor Gilmar Ferreira Mendes ${ }^{55}$ que destaca que apesar de não ser possível do ponto de vista da ciência jurídica

\footnotetext{
${ }^{54}$ DA SILVA, José Afonso, Curso de Direito Constitucional positivo, 35 ed. São Paulo. Editora: Malheiros, 2012. p.41.

${ }^{55}$ MENDES, Gilmar Ferreira \& BRANCO, Paulo Gustavo Gonet. Curso de Direito Constitucional. 8 ed. revisada e atualizada. São Paulo: Editora: Saraiva, 2013. p. 107.
} 
reconhecer um modelo predeterminado de padrão a ser adotado pelo legislador constituinte originário, em especial pela característica do Poder Constituinte ser "incondicionado", "autônomo", "ilimitado", em síntese, com ampla margem de discricionaridade para a elaboração do novo texto constitucional, deve ser reconhecido que ao se efetuar uma análise histórica podemos observar basicamente que a Constituição pode advir das seguintes formas: i) constituição outorgada; ii) constituição votada (quando é promulgada por uma Assembleia de representantes do povo).

Como já foi definido por outros autores, segundo o ensinamento do professor Gilmar Mendes, a Constituição é outorgada quando não há participação popular e o ato constituinte é de responsabilidade de uma única ou pessoa ou de um grupo de pessoas detentores do poder político, como ocorreu ao longo da história nos governos monárquicos e costumaram receber a definição técnica de "Carta Constitucional".

Já no regime publicano e democrático, a forma mais comum de exercício do Poder Constituinte originário é quando a Constituição é promulgada através de uma Assembleia eleita por representantes do povo. Esse método origina a constituição votada.

Mais adiante o renomado autor destaca ${ }^{56}$ que a constituição é votada por dois tipos distintos de procedimentos: o procedimento direto e o representativo, conforme podemos observar pela transcrição da citação abaixo:

"Fala-se, também, em se tratando de Constituição votada, em procedimento constitucional direto, quando o projeto elaborado pela Assembleia obtém validade jurídica por meio de aprovação direta do povo, que se manifesta por meio de plebiscito ou referendo.

Conhece-se a hipótese em que o Governo elabora o projeto da Constituição, que deverá receber a aprovação final da população nas urnas.

Ao lado do procedimento constituinte direto, há a técnica do procedimento constituinte indireto ou representativo. Aqui, a participação do povo esgota-se na eleição dos representantes para uma assembleia, que deverá elaborar e promulgar o texto magno.

\footnotetext{
${ }^{56}$ MENDES, Gilmar Ferreira \& BRANCO, Paulo Gustavo Gonet. Curso de Direito Constitucional. 8 ed. revisada e atualizada. São Paulo: Editora: Saraiva, 2013. p. 108.
} 
Registre-se que, em Estados federais, pode ocorrer de o texto constitucional ter de ser retificado pelos Estados-membros - situação ilustrada pelos Estados Unidos, em 1787".

Aprofundando-nos mais sobre o tema, haja vista a sua relevância para a compreensão da "Teoria do Poder Constituinte", conforme podemos observar na erudita tese de Tatiana Chiradia ${ }^{57}$, ela destaca inicialmente o posicionamento adotado pelo professor Meirelles Teixeira ${ }^{58}$, que sugere um esquema de três etapas para o exercício do Poder Constituinte originário, que pela relevância didática e pela acolhida da tese, julgamos válido discorrer. $\mathrm{O}$ autor descreve os distintos momentos que costumam ocorrer por ocasião da elaboração de um novo texto constitucional, ou seja, como comumente se exerce o Poder Constituinte originário.

Num primeiro momento, segundo o renomado autor, que é anterior ao direito, a comunidade política ("nação") consciente de sua vontade política de existência transforma-se em um Estado.

No segundo momento, também designado de fase "pré-constituinte", após a fundação do Estado o governo provisório, que será escolhido por meio de eleições constituintes que designarão o corpo do novo texto constitucional, irá estruturar o Estado, irá limitá-lo através da edição de uma Constituição ainda incompleta.

$\mathrm{Na}$ terceira e última fase, depois da eleição da Assembleia Constituinte, a Constituição é elaborada e promulgada e passa a vigorar o novo texto constitucional, que deve observar apenas as disposições do bemcomum, o Direito Natural. Depois de promulgada a constituição encerra-se o período constituinte.

\footnotetext{
${ }^{57}$ CHIRADIA, Tatiana Del Giudice Cappa, A essência do Poder Constituinte. Dissertação de Mestrado PUC-SP, Orientador: Professor Doutor Antônio Carlos Mendes, São Paulo, 2009. p. 188.

58 TEIXEIRA, José Horácio Meireles, Curso de Direito Constitucional, Texto revisto e atualizado por Maria Garcia. Rio de Janeiro: Editora: Forense Universitária.p. 205-206.
} 
Efetuando uma análise crítica do modelo defendido pelo professor Meirelles Teixeira, a despeito de todos os seus méritos, podemos perceber com clareza que ele se filia a escola do Direito Natural ou do Jusnaturalismo e este já parte da premissa básica que o Poder Constituinte originário será exercido por meio do povo e que este povo necessariamente terá que ser representado por uma Assembleia Constituinte e esta deverá obrigatoriamente respeitar as disposições do "bem-comum" que existe no seio de determinada sociedade. Tal vinculação da Assembleia Constituinte acaba por desrespeitar de certo modo a característica do "poder ilimitado" do Poder Constituinte originário.

Por outro lado, devemos observar que justamente pelo fato do Poder Constituinte originário possuir como característica ser "incondicionado", como já destaco, não há vinculação obrigatória a qualquer tipo de modelo fixado pelo direito anterior, razão pela qual que na prática o Poder Constituinte originário pode não ser representado diretamente por uma Assembleia Constituinte, mas sim por algum outro método que o legislador constituinte originário julgue mais adequado.

Este entendimento acima explicitado é o que podemos definir como "senso comum" na doutrina constitucionalista e é o que ocorre com maior frequência no âmbito do Direito Estrangeiro.

Embora o objeto do presente trabalho seja efetuar a análise das limitações constitucionais ao poder de reforma da constituição, conforme já destacado na introdução do presente artigo, julgamos ser de especial relevo a compreensão da "Teoria do Poder Constituinte", conforme destacado no item 1.1.

Seguindo esta linha de raciocínio, tecemos essas considerações, pois, entendemos que as limitações que serão impostas ao poder constituinte derivado (ou reformador) serão influenciadas de maneira absoluta pelas limitações impostas pelo Poder Constituinte originário, por ocasião da 
edição e promulgação da nova Constituição, e da institucionalização da nova ordem jurídica.

Nesse diapasão, como podemos observar brevemente neste tópico, a forma de exercício do Poder Constituinte originário, seja de forma democrática ou não democrática, através de uma Assembleia Constituinte ou por plebiscito popular acabar influenciando sobremaneira o "resultado final" que em última análise é a Constituição que inovará o ordenamento jurídico como um todo.

Intuitivamente podemos imaginar, e a experiência empírica comprova esse fato, que uma Constituição que foi outorgada por um ditador ou elaborada por uma elite ou oligarquia detentora circunstancial do poder político certamente imporá limites a sua reforma a fim de manter os privilégios daqueles detentores do poder político, haja vista que um dos objetivos da legislador constituinte originário seja ele "legítimo" ou "ilegítimo" (que será aferido pela anuência ou não da participação popular) objetiva a perenidade da Constituição elaborada e que a mesma produza efeitos jurídicos pelo máximo de tempo possível (característica da "perenidade" que podemos identificar no Poder Constituinte originário).

De igual modo, uma Constituição, cujo exercício do Poder Constituinte originário é fruto de uma revolução também limitará as alterações do texto constitucional, de modo que os princípios básicos que levaram a eclosão da revolução sejam mantidos no texto constitucional. Nesse ponto, no tópico 1.2.1., quando foi analisada as características do Poder Constituinte originário, verificamos que este é um poder que tem a pretensão de se manter perene, permanentemente no tempo, razão pela qual a forma como se manifesta o exercício do Poder Constituinte originário irá influenciar as limitações constitucionais impostas ao poder constituinte reformador. 
Após essa breve digressão, convém analisar as diferentes formas de exercício do Poder Constituinte originário que foram detidamente estudadas na dissertação de mestrado defendida por Tatiana Chiradia. ${ }^{59}$.

A autora gerou uma inovadora abordagem metodológica aonde descreve o exercício do Poder Constitucional originário através de dois modos: i) Por meio de um Ato fundacional; e ii) Ato de Revolução.

No que concerne ao exercício do Poder Constituinte originário através de um "ato fundacional", a autora acabou por sintetizar tudo o que foi exposto no tópico que aqui discorremos. Entretanto, devemos ressaltar que autora compreende que dentro deste conceito de ato fundacional podemos destacar que este exercício pode ser efetuado mediante outorga da Constituição (aí também incluído o modelo de Constituição "Cesarista" ou "Bonapartista") por um soberano ou um grupo detentor do poder político e através da convenção ou Assembleia Constituinte, que pode se encerrar quando a nova Constituição é promulgada, ou após a elaboração do texto, pode que ser que o texto elaborado pela Assembleia seja submetido ao referendo popular (nesse caso trata-se de Poder Constituinte originário exercido na modalidade mista).

A modalidade direta de exercício do Poder Constituinte originário ocorre através da "aclamação" (que autora define como uma "reminênscia histórica") e através de um referendo popular.

A segunda modalidade de exercício do Poder Constituinte originário para a aludida a autora é quando o ato constituinte é movido através de um "ato de revolução", que ocorre quando mudanças estruturais radicais são realizadas no seio de uma sociedade para que seja reestabelecida uma ordem jurídica justa.

\footnotetext{
${ }^{59}$ CHIRADIA, Tatiana Del Giudice Cappa, A essência do Poder Constituinte. Dissertação de Mestrado PUC-SP, Orientador: Professor Doutor Antônio Carlos Mendes, São Paulo, 2009. p. $184-185$.
} 
Podemos definir, do ponto de vista jurídico, a revolução como forma de alteração do modelo constitucional sem a observação dos modelos legítimos para que seja efetuada essa transformação.

Acerca deste tema o jurista Artur Cortez Bonifácio $^{60}$ tece as seguintes considerações:

"Importante dizer, a despeito de abalizados pensamentos, é que a revolução realmente marca o rompimento de um regime político e o início de outro, com ou sem o uso da violência. É inevitável, nesse processo, um Governo de transição, digamos um Governo de fato,e, uma consequente Assembleia Nacional Constituinte, que reflita os valores movimentos revolucionário, pena de incorrer em ilegitimidade e, via extensão, paulatina derrocada da nova ordem".

\subsection{4 - Limitações ao Poder Constituinte Originário}

O objeto de análise do presente trabalho, conforme indicado na introdução, refere-se basicamente as limitações constitucionais ao Poder Constituinte derivado (o poder de reforma da Constituição, seja no plano da Constituição Federal ou no âmbito dos Estados-membros - poder constituinte decorrente).

Antes de atingir este desiderato é essencial, entretanto, conhecer a "Teoria do Poder Constituinte", em especialmente deve ser estudado o Poder Constituinte originário, visto que em última análise é este que irá elaborar os parâmetros que deverão ser observados pelo legislador constituinte derivado.

Nessa toada, deve-se indagar, à luz do que foi exposto no item 1.2.1 (quando elencamos as características do Poder Constituinte originário): existiria algum tipo de limitação ao Poder Constituinte originário?

Numa análise perfunctória pode-se entender que este tópico é absolutamente contraditório, haja vista que conforme já foi abordado no presente trabalho, para a doutrina constitucional predominante as principais

\footnotetext{
${ }^{60}$ BONIFÁCIO, Artur Cortez. Limitações Materiais ao Poder Constituinte Originário, Revista de Direito Constitucional e Internacional. Ano 11. n. 42 - janeiro -março 2003. p. 129.
} 
características do Poder Constituinte originário é de que trata-se de um poder inicial (pois a Constituição é a base de toda a ordem jurídica), ilimitado e autônomo (haja vista não estar vinculado a ordem jurídica anterior por qualquer modo) e incondicionado (por não estar prefixado a nenhuma forma específica para efetuar a sua obra de constitucionalização da nova ordem jurídica).

No sentido do que foi até aqui exposto, suponhamos que no Brasil seja constituída uma Assembleia Nacional Constituinte, democrática, no ano de 2015 para revogar a Constituição Federal de 1988 e a mesma seja promulgada nos trâmites legais previstos para a sua elaboração. Suponhamos também, apenas "por hipótese" que dentre as normas constitucionais da Constituição de 2015 haja uma regra jurídica que a mulher está subordinada ao seu pai ou ao seu marido por ocasião ao casamento, tal como previsto originalmente no Código Civil de 1916. Essa norma constitucional poderia prevalecer?

Ressaltamos, por oportuno, que como já foi analisado no item 1.1 não prevalece na doutrina pátria a teoria da "inconstitucionalidade das normas constitucionais", haja vista que o Supremo Tribunal Federal já rechaçou a doutrina defendida pelo jurista alemão Otto Bachof. (ADI 815) ${ }^{61}$

\footnotetext{
${ }^{61}$ Ementa ADI 815:

EMENTA: - Ação direta de inconstitucionalidade. Parágrafos $1^{\circ}$ e $2^{\circ}$ do artigo 45 da Constituição Federal. - A tese de que há hierarquia entre normas constitucionais originárias dando azo à declaração de inconstitucionalidade de umas em face de outras é incompossível com o sistema de Constituição rígida. - Na atual Carta Magna "compete ao Supremo Tribunal Federal, precipuamente, a guarda da Constituição" (artigo 102, "caput"), o que implica dizer que essa jurisdição lhe é atribuída para impedir que se desrespeite a Constituição como um todo, e não para, com relação a ela, exercer o papel de fiscal do Poder Constituinte originário, a fim de verificar se este teria, ou não, violado os princípios de direito suprapositivo que ele próprio havia incluído no texto da mesma Constituição. - Por outro lado, as cláusulas pétreas não podem ser invocadas para sustentação da tese da inconstitucionalidade de normas constitucionais inferiores em face de normas constitucionais superiores, porquanto a Constituição as prevê apenas como limites ao Poder Constituinte derivado ao rever ou ao emendar a Constituição elaborada pelo Poder Constituinte originário, e não como abarcando normas cuja observância se impôs ao próprio Poder Constituinte originário com relação às outras que não sejam consideradas como cláusulas pétreas, e, portanto, possam ser emendadas. Ação não conhecida por impossibilidade jurídica do pedido. (STF, DJ Nr. do dia 10/05/1996, Rel. Min. MOREIRA ALVES)
} 
Em pleno século XXI tal tese pode parecer absurda (e de fato o é!) a qualquer cidadão brasileiro, razão pela qual podemos afirmar que esta norma não encontra amparo nos anseios sociais da população brasileira contemporânea. Pois bem, do ponto de vista jurídico, à luz da teoria do Poder Constituinte originário, os eventuais representantes do povo (que é o titular real do Poder Constituinte que apenas delegou nesse caso hipotético aos seus representantes escolhidos para compor a Assembleia Constituinte) podem propor esta norma que não está de acordo com os anseios dos seus representados?

No caso acima citado, o legislador constituinte originário está indo ao encontro dos interesses do real detentor da titularidade do Poder Constituinte originário, ou seja, o "povo", razão pela qual intuitivamente podemos entender que tal norma não pode sequer ser proposta pela Assembleia Constituinte.

Vamos um pouco além, nessa hipotética Assembleia Constituinte poderia ser instituída a pena de morte para os que comprovadamente cometerem crimes hediondos, tal como é feito em outros países? Pode ser instituída a pena de castração para presos acusados de crimes envolvendo a violação da liberdade sexual? Poderia acaso ser reduzida a menoridade penal para 12 anos?

Os exemplos acima citados demonstram a importância do estudo das (possíveis) limitações ao Poder Constituinte originário, haja vista que longe de ser um problema meramente acadêmico ou excessivamente teórico, trata-se de tema de extrema relevância para a existência e a manutenção de uma ordem jurídica justa.

Do ponto de vista da sociologia jurídica ou da ciência política, podemos afirmar que a segunda lista de exemplos citadas neste tópico contaria com amplo apoio da população brasileira, haja vista que o senso comum entende, como é notório, que "bandido bom é bandido morto". 
Pode o legislador constituinte originário atender o clamor popular e os anseios da população e institucionalizar o "revanchismo" penal ou para tratarmos em termos mais jurídicos, institucionalizar o "direito penal do inimigo", tal como prevalece em alguns casos, por exemplo, nos Estados Unidos? Em síntese, na fase pré-constitucional deve ser respeitado algum tipo de direito ou realmente "vale tudo"?

Importante ressaltar, que existe uma linha doutrinária defendida pelo jurista lusitano Gomes Canotilho ${ }^{62}$ que defende a impossibilidade da "vedação ao retrocesso" as normas infraconstitucionais, em especial aquelas normas de proteção aos direitos sociais não poderiam ser revogadas, haja vista que são essas normas infraconstitucionais são consideradas como se fossem "constitucionalizadas".

No âmbito da doutrina nacional, destacamos o posicionamento do professor José Vicente dos Santos Mendonça ${ }^{63}$, que defende a existência três possíveis acepções acerca da "vedação ao retrocesso": i) do ponto de vista extrajurídico é considerado "retrocesso" toda a norma que contrarie a opinião pessoal do seu emissor; ii) a segunda é a "vedação genérica ao retrocesso" que preceitua a inconstitucionalidade da revogação de norma infraconstitucional que regulamente ou completa norma constitucional, caso esta norma não seja substituída por outra que mantém a proteção de direitos fundamentais, e; iii) a vedação específica dos direitos fundamentais, que veda que os direitos sociais e fundamentais que são regulamentados por normas infraconstitucionais não poderiam ser revogados ou ter seu alcance limitado por lei posterior.

Pela análise dessa teoria da "vedação ao retrocesso" verificamos que a doutrina que a defende se manifesta acerca da impossibilidade de

\footnotetext{
${ }^{62}$ CANOTILHO, José Joaquim Gomes. Direito Constitucional e Teoria da Constituição. 7 ed. Coimbra: Editora: Livraria Almedina. p. 338-9.

${ }^{63}$ MENDONÇA, José Vicente dos Santos. A vedação do retrocesso: o que é e como perder o medo. In: Gustavo BINENBOJN (Coord.), Revista de Direito da Associação dos Procuradores do Novo Estado do Rio de Janeiro, v. XII, p. 218-9.
} 
alteração ou revogação de normas infraconstitucionais que protegem direitos individuais e sociais.

Essa teoria da "vedação ao retrocesso" também poderia ir além ao que é preceituado pela doutrina, permitindo também que fosse considerada como verdadeira "limitação material ao Poder Constituinte originário", haja vista que os direitos fundamentais e sociais extremamente arraigados no seio da sociedade devem ser respeitados pelo legislador constituinte originário.

No que diz respeito aos estritos limites da ciência jurídica devemos ressaltar que os constitucionalistas vislumbraram limites (justamente para que nesta nova Constituição não prevaleçam estas regras limitativas de direitos) ao Poder Constituinte originário a despeito de sua característica de ser um poder "ilimitado". Nesse passo, convém salientar o posicionamento do professor Gilmar Ferreira Mendes ${ }^{64}$ que assim se manifestou acerca do tema:

"O caráter ilimitado, porém, deve ser entendido em termos. Diz respeito à liberdade do poder constituinte originário com relação a imposições da ordem jurídica que existia anteriormente. Mas haverá limitações 'políticas inerentes ao exercício do poder constituinte.

Se o poder constituinte é a expressão da vontade política da nação, não pode ser entendido sem a referência aos valore éticos, religiosos, culturais que informam essa mesma noção e que motivam as suas ações"

Logo, com base no entendimento acima exposto, devemos considerar que um limite material ao Poder Constituinte originário é justamente os valores "imemoriais", não-escritos, costumeiros, que permeiam determinada sociedade, este núcleo mínimo deve ser respeitado pelo legislador constituinte originário sob pena de não haver legitimidade na nova ordem jurídica criada.

\footnotetext{
${ }^{64}$ MENDES, Gilmar Ferreira \& BRANCO, Paulo Gustavo Gonet. Curso de Direito Constitucional. 8 ed. revisada e atualizada. São Paulo: Editora: Saraiva, 2013. p. 104-105.
} 
Acerca deste delicado tema se manifestou de forma igualmente clara o professor André Ramos Tavares, ${ }^{65}$ se socorrendo de robusta doutrina, entende pela limitação ao Poder Constituinte Originário propriamente dito, senão vejamos:

\begin{abstract}
"Mais adiante o mestre português (Rectius: Jorge Miranda) vai enfatizar que, embora seja mais habitual o aceitar a existência de limites materiais ao poder de revisão constitucional, importa considerar igualmente a existência de limites materiais ao 'poder constituinte verdadeiro e próprio'. Nesse sentido, anota que o poder constituinte não pode se desvincular, no momento da criação da Constituição, de 'certas objetivações históricas que o processo de permanente desalienação do homem vai introduzindo na consciência jurídica geral'. Contatase, nesse passo, a estreita proximidade do pensamento entre JORGE MIRANDA e NELSON DE SOUZA SAMPAIO, ambos se referindo à problemática dos limites materiais do poder constituinte genuíno.

É a ideia, ademais, propugnada por AFONSO QUEIRÓ: 'Uma comunidade política livre, em que o povo seja realmente soberano, não contrariará pela decisão constituinte dos seus representantes essa Constituição material. Esses representantes trairiam o seu mandato, ou excedê-lo-iam se deliberadamente, em algum ponto ou aspecto, se desviassem dela..."”.
\end{abstract}

É absolutamente difícil estabelecer critérios objetivos que o legislador constituinte originário deverá obedecer para que não extrapole os limites mínimos que lhe foram concedidos pelo titular do Poder Constituinte originário, razão pela qual os autores se utilizam de termos abstratos, tais como "consciência jurídica geral" (Jorge Miranda) ou a impossibilidade do legislador constituinte originário violar a "Constituição material" (Afonso Queiró).

Devemos entender, nesse contexto, que cada Estado possui uma série de valores que decorrem do seu próprio desenvolvimento histórico e valores de natureza religiosa, filosófica que estão plenamente vinculados à identidade do povo ou da "nação" e que no final das contas consubstanciaram-se na "Constituição Material", que não poderá ser violada pelo legislador constituinte originário por ocasião da edição do novo texto constitucional.

\footnotetext{
${ }^{65}$ TAVARES, Andre Ramos. Curso de Direito Constitucional. São Paulo: Editora: Saraiva, 2002. p. 39-40.
} 
O professor Gomes Canotilho traça um interessante paralelo entre as características do poder constituinte, tal como concebido por Siéyés na Revolução Francesa, em especial no que concerne ao poder "ilimitado" e "absoluto" como características próprias de atribuições divinas, ou seja, ao Poder Constituinte originário seria lícito o poder de criação a partir do nada, tal como teria feito Deus ao criar todo o universo do nada, segundo a teologia clássica.

Acerca das características do Poder Constituinte originário, o professor André Ramos Tavares ${ }^{66}$ se socorre dos ensinamentos de Genaro Carrió para poder traçar um paralelo entre as características do Poder Constituinte Originário (supremo, absoluto, ilimitado) com as características que as religiões utilizam para conceber a ideia de Deus.

Para o jurista argentino ${ }^{67}$ a origem do Poder Constituinte originário é algo que está além dos limites estritamente jurídicos:

"La noción de poder constituynte originario responde a uma tendecia irreprimible de la rázon: la búsqueda de lo incondicionado. Em este caso loque se busca es uma fuente única, ilimitada y suprema, de toda normácion jurídica y de toda justificación jurídica. Tal fuente, si la hay, está más allá de nuestras possibilidades de conocimiento y de expresión”.

Tal correlação da natureza divina do Poder Constituinte originário também foi estudada pelo professor Gomes Canotilho ${ }^{68}$ :

"Em toda a sua radicalidade, o poder constituinte concebia-se como poder juridicamente desvinculado, podendo fazer tudo como se partisse do nada político, jurídico e social (omnipotência do poder constituinte). Tudo isto estaria na lógica da "teologia política" que envolveu a sua caracterização na Europa da Revolução Francesa (1789). Ao poder constituinte foram reconhecidos tributos divinos: potestas constituem, norma normans, creatio ex nihilo, ou seja o poder de construir, o poder de editar normas, o poder de criação a partir do nada. A associação do poder soberano a poder constituinte - "soberano é aquele que decide sobre a constituição" - concorria para o alicerçamento da ideia de omnipotência constituinte.

\footnotetext{
${ }^{66}$ TAVARES, Andre Ramos. Curso de Direito Constitucional. São Paulo: Editora: Saraiva, 2002.p. 33.

${ }^{67}$ CARRIÓ, Genaro R. Notas sobre Derecho y Lenguage. 4 ed., Buenos Aires: Editora: Abeledo Perrot, 1990. p. 57.

${ }^{68}$ CANOTILHO, José Joaquim Gomes. Direito Constitucional e Teoria da Constituição. 7 ed.

Coimbra: Editora: Livraria Almedina. p. 75.
} 
A doutrina actual rejeita esta compreensão. Desde logo, se o poder constituinte se destina a criar uma constituição concebida como organização e limitação do poder, não se vê como esta "vontade de constituição" pode deixar de condicionar a vontade do criador. Por outro lado, este criador, este sujeito constituinte, este povo ou nação, é estruturado e obedece a padrões e modelos de condutas espirituais, culturais, éticos e sociais radicados na consciência jurídica geral da comunidade e, nesta medida, considerado como "vontade do povo". Além disto, as experiências humanas vão revelando a indispensabilidade de observância de certos princípios de justiça que, independentemente da sua configuração (como princípios suprapositivos ou como princípios supralegais mas intra-jurídicos) são compreendidos como limites da liberdade e omnipotência do poder constituinte. Acresce que um sistema jurídico interno (nacional, estadual) não pode hoje estar out da comunidade internacional. Encontra-se vinculado a princípios de direito internacional (princípio da independência, princípio da autodeterminação, princípio da observância de direitos humanos).

À luz do que foi acima exposto já podemos elaborar respostas as indagações que foram elaboradas no início do tópico.

Nesse sentido, entendemos que o Poder Constituinte originário a despeito de ser considerado como um poder absolutamente "autônomo" e "ilimitado" deverá obrigatoriamente respeitar as regras culturais, sociais, espirituais, as regras que envolvem a proteção de direitos humanos e direitos fundamentais, bem como aquelas normas que o Estado está subordinado por conta do necessário respeito aos Tratados Internacionais aos quais está vinculado, razão pela qual entendemos que nesses casos hipotéticos não seriam lícitos aos legisladores constituinte originários, elaborarem regras de discriminação entre homens e mulheres e lhe seria igualmente vedado estipular normas constitucionais que permitissem a instituição da pena de morte para crimes hediondos, bem como a redução da maioridade penal para 12 anos e também não é lícito a elaboração de normas constitucionais que de qualquer forma permita a castração de presos envolvidos em crimes sexuais.

O entendimento aqui defendido se lastreia na construção com base nos posicionamentos doutrinários acima citados, mas temos a plena consciência que a discussão de tais temas não são de simples solução e 
nosso entender não vem sendo suficientemente tratado pela doutrina, apesar de sua relevância.

Tudo indica, que na hipótese de ser convocada uma Assembleia Nacional Constituinte com a tarefa de elaborar um novo texto constitucional certamente o tema estará mais em voga e tudo indica que a questão da limitação do Poder Constituinte originário será debatida com maior vigor pela doutrina.

Insta salientar que mesmo sob a égide da atual Constituição Brasileira de 1988, mesmo existindo limitações constitucionais expressas ao poder de reforma constitucional muitos parlamentares se arvoram a apresentar projetos de Lei que são absolutamente incompatíveis com os valores sociais, culturais e com a própria "consciência jurídica nacional".

Nesse sentido, confira-se a redação da Proposta de Emenda à Constituição 421/2009 $9^{69}$ de autoria do deputado federal Sabino Castelo Branco do PTB /AM:

"Ementa

Altera a alínea "b" do inciso XLVII do art. $5^{\circ}$ da Constituição Federal, implementando a possibilidade da pena de prisão perpétua nos casos que explicita.

Explicação da Ementa Altera a Constituicão Federal de 1988. Indexação"

É absolutamente razoável supor que numa eventual Assembleia Nacional Constituinte, sem às claras limitações aos representantes populares, esses mesmos projetos podem ser apresentados e quiçá aprovados como normas constitucionais. Nesse caso, ainda que o Supremo Tribunal Federal já tenha assentado o entendimento que não prevalece a tese de Otto Bachof de que haveriam "normas constitucionais

\footnotetext{
${ }^{69}$ Consulta disponível no sítio da Câmara dos Deputados: <http://http://www.camara.gov.br/proposicoesWeb/fichadetramitacao?idProposicao=457071 >. Acesso em 02 de novembro de 2014.
} 
inconstitucionais" deve ser efetuado algum tipo de controle de constitucionalidade para que a norma não tenha eficácia, haja vista que tal norma violaria as limitações materiais impostas ao Poder Constituinte originário.

Em razão da limitação do objeto de nosso trabalho não vamos nos aprofundar acerca deste tema, até porque a hipótese aventada é absolutamente sem precedentes no nosso direito constitucional e exigirá, caso necessário, a resposta dos nossos melhores juristas.

Não poderíamos encerrar este primeiro capítulo sobre a "Teoria do Poder Constituinte" sem deixar de mencionar brevemente sobre a tese do jurista italiano Antonio Negri em sua obra "O poder Constituinte ensaios sobre as alternativas da modernidade", haja vista que o aludido autor afirma de forma clara ${ }^{70}$ que o constitucionalismo tenta conter toda a potência do Poder Constituinte, haja vista que estabelece um quadro pré-fixado que desrespeita as características de "autonomia", por ignorar o caráter "ilimitado" e por "obrigar" a representação através de uma Assembleia Constituinte composta por "representantes do povo" o que para ele é absolutamente incabível, haja vista que a própria multidão é quem deveria de forma diretamente criar o novo ordenamento jurídico, independentemente de qualquer previsão existente no ordenamento jurídico anterior.

O citado autor afirma ainda de forma dura que o constitucionalismo é voltado para o "passado", e a tentativa de regular o poder constituinte é

\footnotetext{
${ }^{70}$ Para um maior aprofundamento da teoria abordada pelo jurista Antonio Negri, mais uma vez indicamos a leitura detalhada da erudita dissertação de mestrado: GUIMARAENS, Francisco De. O poder constituinte no conceito de Antonio Negri - Um conceito muito além da Modernidade hegemônica/ orientador: Carlos Alberto Plastino, Co-Orientador: Adriano Pilatti - Rio de Janeiro, Departamento de Direito. 2002

${ }^{71}$ NEGRI, Antonio. O poder constituinte: ensaio sobre alternativas da modernidade, traduação Adriano Pilatti. Rio de Janeiro: Editora DPeA, 2002. p. 21
} 
"estúpida"72 e ineficiente por não ser capaz de apreender todo o conceito de "poder constituinte".

${ }^{72}$ NEGRI, Antonio. O poder constituinte: ensaio sobre alternativas da modernidade, traduação Adriano Pilatti. Rio de Janeiro: Editora DPeA, 2002. p.21. 


\section{Capítulo II - O Poder Constituinte Derivado}

\subsection{1 - Considerações iniciais acerca do Poder Constituinte Derivado}

Neste segundo capítulo, iremos analisar de forma mais detida o poder constituinte derivado e especialmente as limitações que o constitucionalismo costuma apresentar para regular essa espécie de poder.

Efetuamos a conceituação do "poder constituinte derivado" e destacamos que no âmbito do ordenamento jurídico brasileiro ele se manifesta basicamente por dois modos: através do poder de revisão constitucional e no processo de elaboração da constituição dos estadosmembros, respeitando os limites fixados pela Constituição Federal (poder constituinte decorrente).

Num primeiro momento iremos analisar quais são as características do Poder Constituinte Derivado, qual é a forma do seu exercício e faremos a análise do Poder Constituinte Derivado Decorrente.

Num segundo momento, iremos abordar finalmente acerca das limitações ao Poder Constituinte Derivado Reformador (materiais e formais) em especial as limitações imposta no âmbito da Constituição Federal da República Federal do Brasil de 1988, bem como a abordagem teórica no âmbito do direito estrangeiro.

Serão esses aspectos que serão abordados mais detidamente nos tópicos ao longo do presente capítulo.

\subsection{2 - Características do Poder Constituinte Derivado}

Devemos desde já destacar que o Poder Constituinte derivado possui as seguintes características, como comumente entende ${ }^{73}$ a doutrina constitucionalista, quais sejam: derivado, subordinado e condicionado. 
Nesse sentido é o posicionamento do professor Alexandre de Moraes ${ }^{74} \mathrm{e}$ do professor Augusto Zimmermann ${ }^{75}$.

O professor Manoel Gonçalves Ferreira Filho ${ }^{76}$ traçou uma importante diferenciação entre as características do Poder Constituinte Originário e do Poder Constituinte Derivado, como podemos observar a seguir:

\begin{abstract}
"Em primeiro lugar, o Poder Constituinte originário é um poder inicial; ele cria a ordem jurídica, não é criado pela ordem jurídica. O Poder Constituinte originário é dito ilimitado, ou autônomo, ou soberano, conforme a ordem jurídica. O Poder Constituinte derivado ou instituído é um poder subordinado. O Poder Constituinte derivado ou instituído é um poder subordinado. O Poder Constituinte originário é incondicionado, porque pode manifestar-se dos mais diferentes modos, ou, por outras palavras não tem modo prefixado de manifestação. O Poder Constituinte instituído ou derivado tem um modo especial de sua manifestação que é o modo previsto na Constituição".
\end{abstract}

Pela simples descrição das características do Poder Constituinte derivado verificamos que ele não é detentor de todos os atributos "quase divinos" que o Poder Constituinte originário é detento, ao contrário, é absolutamente limitado pelas limitações impostas por este último.

\title{
2.1.3 - Formas de Exercício do Poder Constituinte derivado
}

Devemos desde logo, mais uma vez, nesse particular, destacar duas espécies distintas de manifestação do Poder Constituinte derivado: Poder Constituinte derivado reformador e Poder Constituinte derivado decorrente.

No âmbito do ordenamento jurídico brasileiro a forma de exercício do Poder Constituinte derivado decorrente ocorre através das Assembleias Legislativas que utilizando-se da prerrogativa prevista no art. 25 da Constituição Federal $^{77}$ e do artigo 11 do $\mathrm{ADCT}^{78}$ elaboraram as

\footnotetext{
${ }^{74}$ MORAES, Alexandre de, Direito Constitucional. 21 ed . São Paulo: Editora: Atlas, 2007. p. 24.

${ }^{75}$ ZIMMERMAN, Augusto, Op. Cit. p. 152.

${ }^{76}$ FERREIRA FILHO, Manoel Gonçalves, $O$ poder constituinte. 3 ed. São Paulo: Editora: Saraiva, 1999. p. 113.

${ }^{77}$ Art. 25 da CF/88: Os Estados organizam-se e regem-se pelas Constituições e leis que adotarem, observados os princípios desta Constituição.

$\S 1^{\circ}$ - São reservadas aos Estados as competências que não lhes sejam vedadas por esta Constituição.
} 
Constituições estaduais, devendo respeitar as limitações impostas pela Constituição Federal.

No que diz respeito ao exercício do Poder Constituinte derivado reformador, no Brasil, o órgão legitimado para proceder à reforma constitucional é o Congresso Nacional, por força do art. 60 da Constituição Federal. ${ }^{79}$ O Presidente da República e as Assembleias Legislativas também são partes legítimas para apresentar a "PEC" (Projeto de Emenda Constitucional)

No âmbito do direito estrangeiro, nos países que respeitam a tradição democrática, o exercício do Poder Constituinte derivado reformado é exercido na sua grande maioria por órgãos de representação popular (o denominado "legislador ordinário").

\subsection{4 - Poder Constituinte derivado decorrente}

O objeto final do nosso objeto de estudo é acerca das limitações constitucionais ao poder de reforma constitucional, ou seja, as limitações constitucionais ao Poder Constituinte Derivado reformador, seja no seio da Constituição Brasileira de 1988 bem como a abordagem da doutrina constitucionalista sobre o tema.

Em que pese às exposições acima expostas, não podemos nos furtar a tecer considerações acerca do Poder Constituinte derivado decorrente, que é o poder que os Estados-membros (em razão de serem dotados de autonomia

\footnotetext{
$\S 2^{\circ}$ - Cabe aos Estados explorar diretamente, ou mediante concessão, os serviços locais de gás canalizado, na forma da lei, vedada a edição de medida provisória para a sua regulamentação. (Redação dada pela Emenda Constitucional no 5, de 1995)

$\S 3^{\circ}$ - Os Estados poderão, mediante lei complementar, instituir regiões metropolitanas, aglomerações urbanas e microrregiões, constituídas por agrupamentos de municípios limítrofes, para integrar a organização, o planejamento e a execução de funções públicas de interesse comum. ${ }^{78}$ Art. 11 ADCT: Cada Assembléia Legislativa, com poderes constituintes, elaborará a Constituição do Estado, no prazo de um ano, contado da promulgação da Constituição Federal, obedecidos os princípios desta.

${ }^{79}$ Art. 60 da CF: A Constituição poderá ser emendada mediante proposta:

I - de um terço, no mínimo, dos membros da Câmara dos Deputados ou do Senado Federal;

II - do Presidente da República;

III - de mais da metade das Assembléias Legislativas das unidades da Federação, manifestando-se, cada uma delas, pela maioria relativa de seus membros.
} 
com base no pacto federativo) possuem para elaborar a Constituição Estadual, bem como a possibilidade de institucionalizar os seus órgãos internos ${ }^{80}$.

O poder decorrente possui como característica o dever de obediência à Constituição Federal (ou seja, aquilo que foi disposto pelo legislador constituinte originário), razão pela qual é considerado como um poder subordinado e condicionado ao Poder Constituinte originário.

Em razão de ser uma mera "decorrência" do texto constitucional que permitiu que os Estados-membros federados, ao exercerem a sua autonomia, elaborassem a Constituição Estadual, devemos considerar que o poder decorrente é um "poder não inicial" ao contrário do Poder Constituinte originário que é um "poder inicial”. Em síntese, a única similitude do Poder Constituinte derivado decorrente com o Poder Constituinte originário é a possibilidade de criar uma Constituição, entretanto, essa possibilidade de "criação" se diferencia deste último em razão de ser também um "poder limitado" e um "poder condicionado".

A titularidade do Poder Constituinte decorrente é o povo da unidade federada e em razão da limitação imposta pela Constituição Federal inexiste a possibilidade de elaboração de "Assembleia Constituinte" no âmbito dos Estados-Membros para fins de elaboração de nova Constituição Estadual.

À luz do que foi exposto acima, devemos destacar que a doutrina constitucionalista majoritária reconhece no poder derivado decorrente a existência de um verdadeiro "poder constituinte", ainda que ele possua todas essas características distintas das existentes no "Poder Constituinte originário".

A fundamentação deste entendimento está lastreada na disposição contida no artigo 18 da Constituição Federal. Essa correlação, conforme

\footnotetext{
${ }^{80}$ CHIRADIA, Tatiana Del Giudice Cappa, A essência do Poder Constituinte. Dissertação de Mestrado PUC-SP, Orientador: Professor Doutor Antônio Carlos Mendes, São Paulo, 2009. p. 199.
} 
citado pelo professor André Ramos Tavares ${ }^{81}$, também foi observada pelo professor Jorge Reinaldo A. Vanossi. Por outro turno, a professora Anna Candida da Cunha Ferraz ${ }^{82}$ explicita que a vinculação da Constituição do Estado-Membro à Constituição Federal é fundamental sob pena de termos um Estado-Soberano ao invés de um Estado-Membro. Esse entendimento é também o que é defendido pelo professor Gilmar Ferreira Mendes que entende que este poder não é um poder soberano e sim um poder que extrai a sua legitimidade da Constituição Federal, estando, portanto, limitado ao conteúdo e à forma previsto pelo legislador constituinte originário. ${ }^{83}$

A Constituição Federal de 1988 por meio do seu Ato de Disposições Constitucionais Transitórias (ADCT), no seu art. $11^{84}$ dispôs expressamente que caberia às Assembleias Legislativas Estuaduais, por meio dos seus representantes eleitos (deputados estaduais) elaborar as Constituições Estaduais.

Importante ressaltar, que a previsão contida no âmbito da Constituição Federal de 1988 demonstra que o legislador constituinte originário reforçou o caráter da autonomia dos entes estaduais em contraponto as Constituições revogadas instituídas durante o período militar. Nesse sentido, convém ressaltar a título exemplificativo, em abono ao que foi aqui afirmado, a análise do art. 188 da Constituição de $1967^{85}$ (onde a Carta Política Federal determinou que as Constituições Estaduais reformassem o seu texto para se adequar as disposições da Constituição Federal) e do art. 200 da Constituição Federal de $1969^{86}$ (quando a Carta

\footnotetext{
${ }^{81}$ TAVARES, Andre Ramos. Curso de Direito Constitucional. São Paulo: Editora: Saraiva, 2002.p. 51.

${ }^{82}$ CUNHA FERRAZ, Ana Candida, Poder Constituinte do Estado-Membro, in Enciclopédia Saraiva do Direito, São Paulo: Editora: Saraiva, 1981, v. 59. p. 20.

${ }^{83}$ MENDES, Gilmar Ferreira \& BRANCO, Paulo Gustavo Gonet., Op. Cit. p. 793.

${ }^{84}$ Art. 11 ADCT: Cada Assembléia Legislativa, com poderes constituintes, elaborará a Constituição do Estado, no prazo de um ano, contado da promulgação da Constituição Federal, obedecidos os princípios desta.

${ }^{85}$ Art. 188 da Constituição Federal de 1967: Os Estados reformarão suas Constituições dentro em sessenta dias, para adaptá-las, no que couber, às normas desta Constituição. as quais, findo esse prazo, considerar-se-ão incorporadas automaticamente às cartas estaduais.

${ }^{86}$ Art. 200 da Constituição Federal de 1969: As disposições constantes desta Constituição ficam incorporadas, no que couber, ao direito constitucional legislado dos Estados.
} 
Política Federal determinou que às Constituições Estaduais deveriam obrigatoriamente incorporar no seu texto constitucional as disposições da Constituição Federal). ${ }^{87}$

Por fim, importante ressaltar, que a doutrina constitucionalista costuma enxergar no Poder Constituinte derivado decorrente dois momentos distintos: i) o denominado Poder Constituinte derivado decorrente incial e ; ii) o Poder Constituinte derivado decorrente de segundo grau (ou de revisão estadual).

O Poder Constituinte Derivado decorrente inicial é o poder que a Constituição Federal outorgou aos Estados-Membros em função da sua capacidade de auto-organização de elaborar as suas Constituições Estaduais, respeitando os limites que foram impostos na própria Constituição Federal.

O Poder Constituinte Derivado decorrente de segundo grau ou de revisão estadual é aquele atinente ao poder que os representantes eleitos do povo de determinado Estado-Membro (Deputados Estaduais ou Deputados Distritais no caso do Distrito Federal), por aplicação do princípio da "simetria" possuem para efetuar a reforma ou emenda à Constituição Estadual, tal como é permitido aos representantes do Congresso Nacional nos termos do art. 60, I, da Constituição Federal de 1988.

\subsection{5. - Limitações Constitucionais ao Poder Constituinte derivado decorrente}

Adotando os critérios estabelecidos pela doutrina pátria mais abalizada, dentre eles o professor José Afonso da Silva ${ }^{88}$ e o professor Gilmar Ferreira Mendes ${ }^{89}$, podemos considerar que no âmbito da Constituição Federal de 1988 foram estabelecidos duas limitações ao Poder

\footnotetext{
${ }^{87}$ DA SILVA, José Afonso, Curso de Direito Constitucional positivo, 35 ed. São Paulo. Editora: Malheiros, 2012. p.611.

${ }^{88}$ Ibid. p.611

${ }^{89}$ MENDES, Gilmar Ferreira \& BRANCO, Paulo Gustavo Gonet. Curso de Direito Constitucional. 8 ed. revisada e atualizada. São Paulo: Editora: Saraiva, 2013. p. 793.
} 
Constituinte derivado decorrente: i) os princípios constitucionais sensíveis, e. ii) os princípios constitucionais estabelecidos. São essas limitações que iremos analisar com maior vagar mais adiante.

As limitações constitucionais decorrentes dos princípios constitucionais sensíveis, segundo o professor José Afonso da Silva ${ }^{90}$, são aquelas limitações que podem ser observados de forma expressa no art. 34, VII, da Constituição Federal de $1988 .{ }^{91}$ que dizem respeito a: i) obrigatoriedade da forma republicana do governo; ii) da obrigatoriedade da adoção sistema representativo do regime democrático; iii) do respeito aos direitos da pessoa humana; iv) da garantia ao princípio da autonomia municipal, e; v) do dever de prestação de contas da administração pública direta e indireta.

Nessa toada, podemos considerar que estes princípios são relativos à organização dos poderes governamentais do Estado que deverão obrigatoriamente seguir o modelo previsto na Constituição Federal.

Com efeito, à luz da Constituição Federal de 1988 não seria cabível que a Assembleia Legislativa do Estado X da federação estabelecesse por meio de emenda à Constituição Estadual que o sistema de governo adotado naquele estado seria o parlamentarismo, por exemplo.

Em respeito ao princípio da simetria também não existe a possiblidade de representação popular a não ser pela eleição por Deputados Estaduais, não podendo por exemplo que por meio de emenda à Constituição Estadual determinado Estado da Federação abolisse a representação "indireta" determinando que a aprovação de todas as leis deveria ser feita "diretamente" por toda a população do Estado como nas cidades-estados gregas.

\footnotetext{
${ }^{90}$ DA SILVA, José Afonso, Curso de Direito Constitucional positivo, 35 ed. São Paulo. Editora: Malheiros, 2012. p.612.

${ }^{91}$ Art. 34, VII, CF de 88: Art. 34. A União não intervirá nos Estados nem no Distrito Federal, exceto para:

(...)

IV - garantir o livre exercício de qualquer dos Poderes nas unidades da Federação;
} 
Conforme explicita Ingo Wolfgang Sarlet ${ }^{92}$ a Constituição Federal de 1988, seguindo a doutrina constitucionalista alemã, em seu artigo 1, inciso III, ${ }^{93}$ estipulou como um dos fundamentos principais do Estado Democrático de Direito o princípio da dignidade humana como um dos princípios norteadores de todo o ordenamento jurídico. Nesse contexto, é óbvio que de forma expressa ou não as Constituições Estaduais deverão obrigatoriamente guardar obediência a este princípio, sob pena de subverter toda a ordem constitucional.

Nessa linha de raciocínio entendemos que caso os agentes públicos dos Estados-Membros cometam violações sistemáticas e reiteradas aos direitos humanos, violando por consequência o princípio da dignidade humana, tal medida poderá ser punida através da sanção mais grave previsto no nossa Carta Constitucional, qual seja a possibilidade de intervenção federal da União Federal no Estado-Membro, com arrimo no disposto no art. 36, III, $\S 3$ da Constituição Federal de $1988^{94}$ após a devida representação pelo Procurador Geral da República perante ao STF.

A Constituição Estadual deverá garantir também de forma expressa a autonomia municipal, não tendo qualquer tipo de ingerência nos Municípios que compõe o seu território, sendo certo que o descumprimento desta norma também poderá ensejar a intervenção federal da União Federal.

\footnotetext{
${ }^{92}$ SARLET, Ingo Wolfgaang, Dignidade da pessoa humana e direitos fundamentais na Constituição Federal de 1988, 4 ed. ver. Atual. - Porto Alegre: Editora: Livraria do Advogado, 2006. p. 62.

${ }^{93}$ Art. 1, III, CF de 88: Art. $1^{\circ}$ A República Federativa do Brasil, formada pela união indissolúvel dos Estados e Municípios e do Distrito Federal, constitui-se em Estado Democrático de Direito e tem como fundamentos:

(...)

III - a dignidade da pessoa humana;

${ }^{94}$ Art. 36. A decretação da intervenção dependerá:

(...)

III de provimento, pelo Supremo Tribunal Federal, de representação do Procurador-Geral da República, na hipótese do art. 34, VII, e no caso de recusa à execução de lei federal.

(...)

$\S 3^{\circ}$ - Nos casos do art. 34, VI e VII, ou do art. 35, IV, dispensada a apreciação pelo Congresso Nacional ou pela Assembléia Legislativa, o decreto limitar-se-á a suspender a execução do ato impugnado, se essa medida bastar ao restabelecimento da normalidade.
} 
É dever de todo administrador probo a apresentação (até em respeito ao princípio constitucional da publicidade previsto no art. 37 da Constituição Federal) das contas públicas e também o dever de responsabilidade com os gastos públicos, razão pela qual essa é mais uma das "limitações expressas" ou "sensíveis" que o legislador constituinte originário submeteu ao legislador constituinte derivado decorrente.

Além das limitações "sensíveis" acima expostas que em razão do seu descumprimento podem gerar a sanção gravíssima da "intervenção federal" nos Estados-membros podemos encontrar outras limitações ao poder constituinte decorrente, qual seja, aquela decorrente dos princípios constitucionais estabelecidos, que para o professor Alexandre de Moraes ${ }^{95}$ seriam as normas constitucionais que limitam a capacidade de autoorganização dos estados-membros de acordo com as regras estabelecidas pela própria Constituição Federal para organização da federação e também estabelecem preceitos que devem ser obedecidos pelos Estados-Membros ao exercerem a sua capacidade de auto-organização. Segundo esse entendimento, estas regras se dividiriam em normas de competência (arts 23; 24;25;27 da Constituição Federal, dentre outros) e normas de preordenação (arts. 27;28; 75, dentre outros).

Existiria ainda um terceiro rol de princípios que limitariam o Poder Constituinte derivado decorrente que seriam os "princípios constitucionais extensíveis". Para o professor José Afonso da Silva ${ }^{96}$ teriam sido praticamente sido eliminados pela atual Constituição Federal de 1988 em respeito ao federalismo. O professor Raul Machado Horta qualifica estes princípios como os "princípios desta Constituição", haja vista que são aqueles princípios que são normais de obrigatoriedade comum pela União Federal, pelos Estados-Membros, pelos Municípios e pelo Distrito Federal, razão pela qual, por óbvio, devem ser respeitados pelo legislador

\footnotetext{
${ }^{95}$ MORAES, Alexandre de, Direito Constitucional. 21 ed . São Paulo: Editora: Atlas, 2007. p. 257.

${ }_{96}$ DA SILVA, José Afonso, Curso de Direito Constitucional positivo, 35 ed. São Paulo. Editora: Malheiros, 2012. p.62.
} 
constituinte derivado decorrente por ocasião da alteração e elaboração da Constituição Estadual.

\subsection{6. - Poder Constituinte derivado reformador}

Conforme bem observado pelo professor José Afonso da Silva ${ }^{97}$ a doutrina constitucionalista pátria costuma diferenciar três formas distintas de manifestação do Poder Constituinte derivado reformador, quais sejam: emenda constitucional e revisão constitucional, ambos incluídos dentro do gênero "reforma constitucional".

Na Constituição Federal de 1988 em seu art. 3 do $\mathrm{ADCT}^{98}$ previu a possibilidade de ser efetuada uma revisão do seu texto, até para que a população pudesse optar pelo sistema parlamentarista ou presidencialista. Podemos considerar que a revisão constitucional exige procedimentos mais rígidos e mais lentos dos que aqueles previstos na emenda constitucional, haja vista que objetiva a maior estabilidade da Constituição ${ }^{99}$, tal revisão objetiva na maioria das vezes adequar o proposto pelo legislador constituinte originário a aplicação e eficácia das normas constitucionais no seio de determinada sociedade.

O processo de emenda à Constituição Federal, no Brasil, deve respeitar o disposto no art. 60 da Carta Política Federal. Podemos conceituar a "emenda à constituição" como procedimento previsto pelo legislador constituinte originário para que fosse possível pelo legislador constituinte derivado (ou ordinário) a alteração de determinados pontos da Constituição que não são elementos essenciais da Constituição Federal, ainda que na prática tenha que cumprir um processo legislativo mais rigoroso do que aquele previsto para a edição das leis ordinárias. Nessa

\footnotetext{
${ }^{97}$ DA SILVA, José Afonso, Curso de Direito Constitucional positivo, 35 ed. São Paulo. Editora: Malheiros, 2012. p. 62.

${ }^{98}$ Art. 3 ADCT:A revisão constitucional será realizada após cinco anos, contados da promulgação da Constituição, pelo voto da maioria absoluta dos membros do Congresso Nacional, em sessão unicameral.

${ }^{99}$ DA SILVA, José Afonso, Curso de Direito Constitucional positivo, 35 ed. São Paulo. Editora: Malheiros, 2012. p.62.
} 
toada, podemos considerar que a "reforma constitucional" é quando ocorre qualquer tipo de alteração expressa da Constituição Federal, seja através da edição de uma Emenda Constitucional ou através de revisão constitucional. ${ }^{100}$.

Conforme bem observado pela Ministra do Supremo Tribunal Federal Carmen Lúcia Antunes Rocha ${ }^{101}$, o homem está em constante evolução e também assim deve acontecer com o ordenamento jurídico, razão pela qual a Constituição deve evoluir em conjunto com o homem. Nesse passo é válido transcrever a inteligente e poética definição da autora $^{102}$ :

\begin{abstract}
"Neste final de século, a Constituição apresenta-se como Lei Magna sim, mas impulsionadora de uma efetiva justiça, sem nada retórico ou apenas formal. Tudo que nela se contenha deve ter vida e vez na evolução social, e a margem com que ela baliza os comportamentos públicos e privados é marcada pelo sentimento e pelo pensamento do povo que a inspira. A Constituição ganhou, contemporaneamente, uma concretude imediatista antes inexistente ou não relevada com a mesma exigência de agora. Mas as novas exigências em que se envolve a Lei Magna não substituem, acrescentam à segurança. A qualidade de instrumento normativo estável e estabilizador do direito continua a timbrar o sistema constitucional, embora se reconheça que tal característica não o dota de imobilidade.
\end{abstract}

A Constituição agora é mais o cidadão no mundo do que o indivíduo no Estado como foi antes.

O Estado tem, em seu aparato burocrático, um arrastar de pés que preferem o descanso na mesma posição. O povo tem um fremir permanente das pernas que se lançam num andar sem fim em busca de seus ideais. A Constituição não pode pré-traçar o caminho da História. Pode e deve, contudo abrir o espaço a aplanar a andança na senda preferida pelo homem. Não pode lhe reduzir a trilha, não deve antepor muralhas nas veredas que marcha o ser humano. Se a constituição se converter em amarras a impedir a opção da sociedade, esta romperá as correntes da Lei e a debandará, ainda que sem normas e com menores chances de sobrevivência, por outros atalhos.

(...)

A Constituição não pode ter gosto do dia anterior; deve ter sempre o sabor de hoje, numa boa perspectiva do amanhã.

Não se deseja a Constituição como o túmulo das normas, ou que seja a mortalha de uma ideia de justiça. Quer-se a Constituição que seja o canteiro no qual se possa semear e fazer brotar uma justiça verdadeira, vivida no diaa-dia de cada pessoa".

\footnotetext{
${ }^{100}$ DA SILVA, José Afonso, Curso de Direito Constitucional positivo, 35 ed. São Paulo. Editora: Malheiros, 2012. p.62.

${ }^{101}$ Remetemos ao leitor a leitura do artigo de ANTUNES ROCHA, Carmen Lúcia, Constituição $e$ mudança constitucional: limites ao poder de reforma constitucional, Revista de Informação Legislativa, Brasília, out/ dezembro de 1993, n. 120. p. 160-161.

102 Ibid. p. 161-162
} 
(grifos nossos)

Como bem observado pela professora mineira a Constituição não pode ficar imobilizada no tempo e também não tem a capacidade "clarividente" de prever as crises constitucionais que ocorrerão que poderão colocar em risco a estabilidade constitucional, razão pela qual, para que o homem possa se realizar e alcançar os seus objetivos dentro da sociedade, deve ser possível a transformação do ordenamento jurídico para que este se compatibilize com a realidade social. Esta afirmação possui ainda mais relevo quando se trata da Constituição Federal que é a norma que é considerada como a Lei Fundamental e a norma da qual todas as demais normas do ordenamento jurídico extraem seu fundamento de validade, motivo pelo qual a Constituição possa ser capaz de concretizar a justiça na sociedade.

A reforma constitucional possui natureza de poder constituinte e é uma forma racional que foi encontrada pelo legislador constituinte originário para efetuar uma alteração formal, racional e eficiente do texto constitucional a fim de que ele acompanhe o "espírito constitucional" de determinada sociedade e não fique incompatível, tornando-se assim mais frágil a eventual ruptura da ordem jurídica com a edição de uma nova Constituição por meio do exercício do Poder Constituinte originário.

\subsection{7. - Espécies de Limitação ao Poder Constituinte Derivado} de Reforma.

A doutrina constitucionalista costuma elencar em três grupos distintos as espécies de limitações ao Poder Constituinte derivado reformador que são: limitações materiais (explícitas e implícitas), limitações temporais e limitações circunstanciais. ${ }^{103}$. O professor Alexandre de Moraes efetua a diferenciação em duas classes distintas: i)

\footnotetext{
${ }^{103}$ DA SILVA, José Afonso, Curso de Direito Constitucional positivo, 35 ed. São Paulo. Editora: Malheiros, 2012. p.66.
} 
limitações expressas (onde se encontrariam as limitações materiais, circunstanciais e as limitações formais) e; ii) limitações implícitas (aquelas que não estariam formalmente dispostas pelo legislador constituinte originário mas que devem existir sob pena de ser afetada a lógica do sistema constitucional). ${ }^{104}$

Nos tópicos a seguir iremos analisar as espécies acima elencadas, em especial aquelas que foram aplicadas historicamente no sistema institucional brasileiro.

\subsection{8. - As limitações materiais ao Poder Constituinte Derivado de Reforma.}

As limitações materiais são aquelas limitações que o Poder Constituinte originário, por ocasião da elaboração do novo texto constitucional, impõem ao Poder Constituinte derivado, impedindo que este efetue modificações em temas fundamentais, denominado comumente de "núcleo imodificável" ou "núcleo essencial do projeto do poder constituinte originário". ${ }^{105}$

A principal discussão travada pela doutrina constitucional seria acerca da legitimidade e da suposta possibilidade de uma geração vincular as gerações futuras de acordo com os seus próprios projetos e ideais políticos através da elaboração de um texto constitucional. ${ }^{106}$

Em linhas gerais, podemos afirmar que esta linha de argumentação não prevalece mais entre os constitucionalistas, haja vista que do ponto de vista da práxis política, verificou-se a necessidade de efetuar mudanças pontuais no texto constitucional, até para que possa ser mantida a

\footnotetext{
${ }^{104}$ MORAES, Alexandre de, Direito Constitucional. 21 ed . São Paulo: Editora: Atlas, 2007. p. 637.

${ }^{105}$ MENDES, Gilmar Ferreira \& BRANCO, Paulo Gustavo Gonet. Curso de Direito Constitucional. 8 ed. revisada e atualizada. São Paulo: Editora: Saraiva, 2013. p. 121.

${ }^{106}$ CANOTILHO, José Joaquim Gomes. Direito Constitucional e Teoria da Constituição. 7 ed. Coimbra: Editora: Livraria Almedina. p. 943.
} 
perpetuidade e perenidade do texto constitucional, permitindo-o que este se adeque as alterações existentes na sociedade. ${ }^{107}$

Por outro turno é essencial destacar que inexiste a vinculação de uma geração aos ideais e preceitos políticos defendidos pelas gerações passadas, haja vista que o "povo", como visto no item 1.2.2, é o legítimo titular do Poder Constituinte originário e se este não exercer a sua capacidade de exercício deste "poder" para elaboração de um novo texto constitucional é um sinal indicador que há bem da verdade esta geração concorda "implicitamente" com as limitações que lhe foram impostas pelas gerações anteriores. ${ }^{108}$

Ainda no que concerne a este tópico aos limites materiais ao Poder Constituinte derivado de reforma, o professor Gomes Canotilho elenca alguns conceitos que merecem análise em razão da acolhida pela doutrina constitucional. $\mathrm{O}$ autor português efetua a seguinte classificação: i) limites superiores e inferiores; ii) limites expressos e limites tácitos e; iii) limites absolutos e relativos.

Para o autor ${ }^{109}$ os "limites materiais inferiores" ao Poder Constituinte derivado de reforma tratam acerca da possibilidade de uma emenda constitucional (ou "lei de revisão") inserir na Constituição qualquer tipo de matéria, ou seja, se existiria uma espécie de "reserva de lei constitucional".

$\mathrm{O}$ autor entende que inexiste uma "reserva de matéria constitucional", que deve ser obrigatoriamente seguir a forma constitucional pelo legislador constituinte derivado. ${ }^{110}$ Nesse sentido, seria possível a inserção na Constituição de qualquer matéria, e não apenas, por exemplo,

\footnotetext{
${ }^{107}$ Acerca deste tema e sobre a importância de se efetuar alterações no texto constitucional remetemos ao leitor mais uma vez a leitura do artigo de ANTUNES ROCHA, Carmen Lúcia, Constituição e mudança constitucional: limites ao poder de reforma constitucional, Revista de Informação Legislativa, Brasília, out /dezembro de 1993, n. 120. p. 160-161.

${ }^{108}$ MENDES, Gilmar Ferreira \& BRANCO, Paulo Gustavo Gonet. Curso de Direito Constitucional. 8 ed. revisada e atualizada. São Paulo: Editora: Saraiva, 2013. p. 121-122.

${ }^{109}$ CANOTILHO, José Joaquim Gomes. Direito Constitucional e Teoria da Constituição. 7 ed. Coimbra: Editora: Livraria Almedina p. 942.

${ }^{110}$ Ibid. p. 942 .
} 
que tratam das limitações ao poder do Estado, a estruturação deste poder, os direitos e garantias individuais dos cidadãos (matérias eminentemente de cunho constitucional).

No âmbito do sistema constitucional brasileiro, importante ressaltar que na Constituição Imperial de 1824 , no art. $178^{111}$ efetuou a distinção entre matérias constitucionais e matérias não-constitucionais. Apenas as primeiras poderiam ser modificadas através do processo mais rigoroso de Emenda à Constituição. Todas as demais normais ainda que formalmente inseridas no texto constitucional, mas que não tratavam legitimamente de matéria constitucional, poderiam ser alteradas por mera "lei ordinária". Esse sistema do ponto de vista da segurança jurídica foi bastante tormentoso, haja vista que o Poder Legislativo naquele período debatia infinitamente se determinada norma da Constituição era efetivamente ou não constitucional para que fosse possível perquirir a forma de modificação do texto constitucional (por lei ordinária ou por emenda à Constituição).

Nesse particular, acerca das "limitações constitucionais inferiores", devemos ressaltar que esse sistema adotado pelo Constituinte de 1824 não foi mais adotado pelos demais legisladores constituintes originários por ocasião da elaboração das Constituições subsequentes, devendo ser ressaltado que no âmbito da Constituição Federal de 1988, no art. 242, § $2^{\text {o112}}$, chegou ao cúmulo de definir que o Colégio Pedro II localizado na cidade do Rio de Janeiro permanecerá sob a esfera de tutela da União Federal.

Outro ponto destacado pelo professor Gomes Canotilho é sobre os "limites superiores" existentes como limitações ao poder de revisão que diz

\footnotetext{
${ }^{111}$ Art. 178 Constituição de 1824: E' só Constitucional o que diz respeito aos limites, e attribuições respectivas dos Poderes Politicos, e aos Direitos Politicos, e individuaes dos Cidadãos. Tudo, o que não é Constitucional, póde ser alterado sem as formalidades referidas, pelas Legislaturas ordinarias.

${ }^{112}$ Art. 242, $\S 2^{\circ}$, CF de 88:. O princípio do art. 206, IV, não se aplica às instituições educacionais oficiais criadas por lei estadual ou municipal e existentes na data da promulgação desta Constituição, que não sejam total ou preponderantemente mantidas com recursos públicos. (...) $\S 2^{\circ}$ - O Colégio Pedro II, localizado na cidade do Rio de Janeiro, será mantido na órbita federal.
} 
respeito à possibilidade de todas as normas da Constituição serem objeto de alteração através do processo de emenda à Constituição. O autor reconhece que nem todas as normas da Constituição podem ser alteradas, haja vista que algumas delas são consideradas como o "cerne da Constituição" ${ }^{113} \mathrm{e}$, portanto, imodificáveis.

Como já foi abordado, no sistema brasileiro constitucional é da própria essência das "limitações materiais" a preservação de um "núcleo imodificável", razão pela qual no Brasil não é possível efetuar por meio de emenda à Constituição a alteração de alguns temas centrais, em especial aqueles previstos no art. 60, $\S 4^{114}$, da Constituição Federal de 1988.

Seguindo na linha de classificação dos limites materiais abordada por Gomes Canotilho teríamos também "limites materiais expressos" e "limites materiais tácitos"(ou implícitos).

Os limites materiais expressos ou textuais seriam aqueles limites previstos no corpo do próprio texto constitucional, impostos pelo legislador constituinte originário. ${ }^{115}$ No Brasil, no âmbito da Constituição Federal de 1988, os limites materiais expressos estão no art. 60 , $\$ 4$.

Ressalta o autor português que muitas vezes, no seio das Constituições, opta o legislador constituinte originário em não estipular quaisquer tipos de regras expressas acerca das limitações ao poder de reforma. Esses valores podem decorrer de uma ordem de valores prépositivos vinculados à "ordem constitucional concreta". ${ }^{116}$

\footnotetext{
113 Ibid.

${ }^{114}$ Art. $60, \S 4^{\circ} \mathrm{CF}$ : A Constituição poderá ser emendada mediante proposta: (...)

$\S 4^{\circ}$ - Não será objeto de deliberação a proposta de emenda tendente a abolir:

I - a forma federativa de Estado;

II - o voto direto, secreto, universal e periódico;

III - a separação dos Poderes;

IV - os direitos e garantias individuais.

${ }^{115}$ CANOTILHO, José Joaquim Gomes. Direito Constitucional e Teoria da Constituição. 7 ed. Coimbra: Editora: Livraria Almedina. p. 942.

${ }^{116}$ CANOTILHO, José Joaquim Gomes. Direito Constitucional e Teoria da Constituição. 7 ed.

Coimbra: Editora: Livraria Almedina. p. 943.
} 
No Brasil, o professor José Afonso da Silva, se inspirando no magistério de Nelson de Souza Sampaio, compreende a existência de três formas existentes de limites implícitos ao legislador constituinte derivado ${ }^{117}$, quais sejam: i) as concernentes ao titular do poder constituinte; ii) as referentes ao titular do poder reformador,e; iii) as relativas aos processos da própria emenda. Iremos detalhar todos esses pontos mais abaixo.

O professor Nelson de Souza Sampaio ao analisar essas espécies de limitações materiais implícitas ao poder de reforma da Constituição estava objetivando efetuar a análise de "legitimidade constitucional", onde efetuou a análise dos princípios que apesar de não serem escritos ou estarem expressamente previstos no texto constitucional, servem como fundamento para a Constituição Federal e devem ser consideradas pelo intérprete por ocasião da interpretação do texto constitucional e também para auferir a legalidade ou não da reforma constitucional. ${ }^{118}$

Nesse diapasão, podemos considerar que não é lícito ao poder constituinte derivado efetuar por meio de emenda ou revisão à constituição a alteração do titular do Poder Constituinte originário, haja vista que este o titular legítimo deste poder é o povo e sempre que este entender que o modelo constitucional em vigor não atende mais aos anseios sociais pode exercer esse direito para a criação de uma nova Carta Constitucional.

A impossibilidade de alteração do titular do Poder Constituinte originário pelo legislador constituinte derivado decorre também da própria lógica do sistema, haja vista que o Poder Constituinte derivado foi criado pelo Poder Constituinte originário e de modo algum poderá aquele dispor de um poder que não lhe pertence, ou seja, ainda que por qualquer tipo de contingência política o Poder Constituinte derivado entenda por bem efetuar

\footnotetext{
${ }^{117}$ DA SILVA, José Afonso, Curso de Direito Constitucional positivo, 35 ed. São Paulo. Editora: Malheiros, 2012. p.68.

${ }^{118}$ TAVARES, Andre Ramos. Curso de Direito Constitucional. São Paulo: Editora: Saraiva, 2002. p. 50.
} 
a mudança da titularidade do Poder Constituinte originário ele não poderá fazê-lo de forma legítima, haja vista que um Poder Constituído não pode dispor sobre a forma de exercício de um poder constituinte, ou seja, não pode dispor de um poder que não possui. ${ }^{119}$

Por outro vértice, devemos considerar também, no que concerne a titularidade do exercício do Poder Constituinte, que não é lícito ao Poder Constituinte derivado reformador efetuar a alteração do titular deste poder, haja vista que compete apenas ao legislador constituinte originário dispor sobre o órgão legítimo para proceder a alteração da Constituição Federal, sendo esta regra, portanto, de natureza intangível e imodificável, essencial ao próprio sistema constitucional, não podendo ser alterada através do processo de emenda à constituição ou no eventual processo de revisão constitucional.

A lógica desta regra decorre da necessidade de se garantir a essência e os núcleos fundamentais do texto constitucional. Se por qualquer hipótese fosse alterada o titular do Poder Constituinte derivado reformador de forma distinta ao que foi previsto pelo legislador constituinte originário, haveria aí também uma usurpação ilegítima do poder constituinte, haja vista que cabe apenas ao legislador ordinário regular qual é o órgão legítimo (normalmente o grupo político de representantes eleitos pelos cidadãos) para proceder a relevante tarefa de alteração do texto constitucional, que em última análise busca a adequação daqueles valores constitucionais preconizados pelo legislador constituinte originário com os anseios sociais que são mutáveis e exigem alteração de acordo com o passar do tempo para que a “Constituição jurídica” esteja de acordo com a "Constituição real".

Com efeito, tendo em vista a relevância do Poder Constituinte derivado, é natural a compreensão que qualquer alteração no titular do exercício deste poder consubstancia-se em um modo de "burlar" a

\footnotetext{
${ }^{119}$ SAMPAIO, Nelson de Souza. O poder de Reforma Constitucional. 3 ed. Belo Horizonte. Editora: Nova Alvorada edições, 1995. p. 97.
} 
Constituição (o que os constitucionalistas denominam como "fraude à constituição"), razão pela qual esta é considerada como uma limitação implícita sem a qual o sistema constitucional não teria racionalidade.

Por fim, seguindo o magistério de Nelson de Souza Sampaio, a última das limitações materiais implícitas ao processo de reforma constitucional é que não seria lícito ao Poder Constituinte derivado efetuar alterações nos procedimentos legais necessários para a reforma constitucional, ou seja, não seria lícito ao legislador constituinte derivado, por exemplo, simplificar o procedimento para alteração do texto constitucional, simplificando-o e o tornando semelhante ao processo para alteração ou a edição de legislação ordinária (ou infraconstitucional).

O objetivo desta regra é reconhecer e garantir a "supremacia da Constituição" reconhecendo que por se tratar da principal norma jurídica do ordenamento jurídico, sob a qual todas as demais normas deverão guardar obediência e compatibilidade material, seguindo a lógica da estrutura escalonada do ordenamento jurídico proposta por Hans Kelsen, não poderia ser alterada de forma mais simplificada do que estipulada pelo legislador constituinte originário por ocasião da elaboração e promulgação do texto constitucional. O que visa ser preservado aqui, mais uma vez, é que os valores constitucionais que nortearam a elaboração do texto constitucional sejam "fraudados" ou "burlados" através de uma suposta "reforma constitucional" que na realidade objetiva romper com o ordenamento jurídico vigente.

Como já explanado ao longo do primeiro capítulo do presente trabalho a ruptura do ordenamento jurídico de forma legítima só pode ocorrer através da vontade do "povo", no exercício da titularidade do Poder Constituinte originário e jamais poderá ocorrer de forma ilegítima através de supostas alterações que a pretexto de "reformar" o texto constitucional a bem da verdade rompem com o ordenamento jurídico vigente. Não é por outro motivo, que no caso do Brasil, grande parte da doutrina 
constitucionalista pátria entende que a Emenda Constitucional n. 1 de 1969 (emenda à Constituição Federal de 1967 que passou a vigorar em 30.10.1969) apesar de possuir o nomen iuris de "emenda à constituição" materialmente tratava-se na realidade de uma nova Constituição Federal outorgada por um meio ilegítimo, justamente por não haver respeitado a este limites implícitos ao procedimento de reforma constitucional.

Para o professor Nelson de Souza Sampaio ${ }^{120}$ a única atenuação desta regra aceitável do ponto de vista da lógica jurídica seria a elaboração de emenda à constituição ou através de "revisão constitucional", se fosse o caso, que objetivasse alterar as regras para alteração do texto constitucional, tornando-o um processo legislativo mais rigoroso ao que foi previsto pelo legislador constituinte originário. Dessa forma, o princípio da "supremacia da Constituição" e a rigidez constitucional continuariam protegidos, a bem da verdade seriam até ampliados, razão pela qual não haveria qualquer ilegalidade nesta alteração constitucional.

A limitação material implícita a reforma do texto constitucional defendida pelo professor Nelson de Souza Sampaio vai ao encontro a tese da "dupla revisão" defendida pelo jurista português Jorge Miranda ${ }^{121}$. Esta tese da "dupla revisão" entende que haveria a possibilidade da reforma da "parte intangível" do texto constitucional, ao "núcleo essencial", desde que anteriormente fosse efetuada uma revisão constitucional permitindo a alteração das cláusulas limitativas da Constituição Federal, ou seja, inicialmente caberia ao legislador constituinte derivado efetuar uma alteração nas regras constitucionais que preveem a limitação ao poder de reforma constitucional e num segundo momento, respeitando este novo regramento, efetuar a alteração de parte do "núcleo imodificável" que originariamente estava vedado pelo legislador constituinte originário. A única ressalva que o jurista português efetua é que haveria

\footnotetext{
${ }^{120}$ SAMPAIO, Nelson de Souza. O poder de Reforma Constitucional. 3 ed. Belo Horizonte. Editora: Nova Alvorada edições, 1995. p. 107.

${ }^{121}$ MIRANDA, Jorge, Manual de Direito Constitucional. TOMO II. Introdução a teoria da Constituição. 2 ed. Coimbra: Editora: Coimbra. 1983.p. 179.
} 
inconstitucionalidade na "dupla revisão" quando se constatasse a violação aos princípios fundamentais ${ }^{122}$.

$\mathrm{O}$ entendimento que predomina na doutrina constitucionalista majoritária é que esta tese legitimaria na prática a "Fraude à Constituição" (Verfassungsbeseitigung), como defendido pelo professor José Afonso da Silva $^{123}$ e pelo também professor Gomes Canotilho ${ }^{124}$. O fundamento central para considerar pela inaplicabilidade da aludida tese é que um dos fundamentos essenciais ao direito é que não é lícito a ninguém outorgar mais poderes que possui. O Poder Constituinte derivado reformador não possui a legitimidade de exercer os poder constituídos pelo Poder Constituinte originário, razão pela qual não há como prosperar essa tese, devendo ser considerada como inconstitucional qualquer norma que vise à alteração do procedimento de reforma constitucional, salvo quando o projeto de emenda à constituição vise dificultar o processo legal para a reforma constitucional.

Ante o exposto, importante destacar, que as limitações implícitas estão difundidas nas regras constitucionais. Temos alguns claros exemplos que comprovam esta afirmação. A disposição contida no art. 1 da Constituição Federal de $1988^{125}$, que elenca os fundamentos da República Federativa do Brasil, são claras indicações de limitações implícitas impostas pelo legislador constituinte originário e que não podem ser modificadas pelo legislador constituinte derivado. Nesse sentido, dentre as regras constitucionais, podemos citar as disposições contidas no parágrafo único do art. $1^{126}$ da Constituição Federal que qualifica o povo como fonte

\footnotetext{
${ }^{122}$ MIRANDA, Jorge, Manual de Direito Constitucional. TOMO II. Introdução a teoria da Constituição. 2 ed. Coimbra: Editora: Coimbra. 1983. p. 187.

${ }^{123}$ DA SILVA. José Afonso. Comentário Contextual à Constituição. São Paulo:Editora: Malheiros, 2005, p. 442.

${ }^{124}$ CANOTILHO, José Joaquim Gomes. Direito Constitucional e Teoria da Constituição. 7 ed. Coimbra: Editora: Livraria Almedina. p. 943.

${ }^{125}$ Art. 1 CF 88: A República Federativa do Brasil, formada pela união indissolúvel dos Estados e Municípios e do Distrito Federal, constitui-se em Estado Democrático de Direito e tem como fundamentos:

${ }^{126}$ PÙ, Art. 1 CF 88: Parágrafo único. Todo o poder emana do povo, que o exerce por meio de representantes eleitos ou diretamente, nos termos desta Constituição.
} 
de todo o poder (certamente não será possível a edição de emenda à Constituição alterando esta regra constitucional). Estes são apenas alguns dos exemplos dos princípios constitucionais fundamentais que estão distribuídos ao longo da Carta Constitucional e que não poderão ser objeto de reforma constitucional pelo legislador constituinte derivado.

Com a análise dos limites materiais implícitos apontados pela doutrina vamos analisar a última classificação elaborada pelo professor Gomes Canotilho no que concerne às limitações materiais ao Poder Constituinte derivado, com o estudo dos denominados "limites absolutos" e dos "limites relativos".

Para o professor os limites materiais absolutos ${ }^{127}$ seriam todos aqueles limites existentes na Constituição que não poderiam ser revistos, ou seja, que não poderiam ser superados pelo exercício de um poder de revisão. Essa classificação não seria aceitável para aqueles juristas que advogam a tese do "duplo poder de revisão", como o professor lusitano Jorge Miranda, haja vista que para estes autores inexistiria norma constitucional que não poderia ser superada pelo poder de revisão, caso fosse seguido os procedimentos exigidos para a "dupla revisão", salvo o reconhecimento posterior de inconstitucionalidade na hipótese de ofensa a direitos fundamentais.

Por fim, os limites materiais relativos são aqueles que condicionam o exercício do poder de revisão, mas que não impedem a alteração das normas constitucionais, desde que cumpridas as condições mais impeditivas estabelecidas por esse limite material relativo ${ }^{128}$. Trata-se em síntese seriam daquelas normas que, por exemplo, alteram o processo de reforma constitucional tornando o procedimento mais difícil para alteração do texto constitucional, tornando a Constituição ainda mais "rígida".

\footnotetext{
${ }^{127}$ CANOTILHO, José Joaquim Gomes. Direito Constitucional e Teoria da Constituição. 7 ed. Coimbra: Editora: Livraria Almedina. p. 944.

${ }^{128}$ Ibid. p. $944-945$.
} 


\subsection{9. - As limitações materiais na Constituição Federal de} 1988.

As limitações materiais existentes no âmbito da Constituição Federal de 1988 se manifestam na proteção que o legislador constituinte originário ofereceu com relação as denominadas "cláusulas pétreas". Essas normas fazem parte do "núcleo imodificável" da Constituição Federal e que objetiva inibir a tentativa de destruição dos valores constitucionais básicos pelo legislador constituinte derivado encarregado de efetuar a alteração do texto constitucional. O objetivo é impedir que as circunstâncias políticas ocasionais coloquem em risco o projeto duradouro da Carta Constitucional, ou seja, na realidade estas normas protegem a democracia e podem ser consideradas como o "cerne" da Constituição. ${ }^{129}$

Os limites materiais são essenciais para a preservação do funcionamento do Estado Democrático de Direito tal como defendido pelo legislador constituinte originário, razão pela qual entendemos que a interpretação destas normas devem ser efetuadas pelo intérprete de forma "ampliativa" e não "restritiva" para que possam ser albergadas todos os direitos e garantidos necessários para o bom funcionamento do ordenamento jurídico. Em que pese a análise das classificações apontadas pelos juristas servirem como norte orientador do tema, devemos considerar que as "cláusulas pétreas" são as matérias de principal relevo dentro do estudo do direito constitucional, haja vista que este "núcleo imutável” é que garante em última análise a eficácia, a aplicabilidade, e a supremacia do texto constitucional no ordenamento jurídico, bem como dos princípios previstos no texto constitucional.

As denominadas cláusulas pétreas estão inscritas no texto constitucional no art. $60, \S 4$, da Constituição Federal $^{130}$ e vedam

\footnotetext{
${ }^{129}$ MENDES, Gilmar Ferreira \& BRANCO, Paulo Gustavo Gonet. Curso de Direito Constitucional. 8 ed. revisada e atualizada. São Paulo: Editora: Saraiva, 2013. p. 123.

${ }^{130}$ Art. $60, \S 4, \mathrm{CF}$ de 88: A Constituição poderá ser emendada mediante proposta: (...)
} 
expressamente a reforma do texto constitucional de emendas tendentes a abolir: i) a forma federativa do Estado; ii) o voto direto, secreto, universal e periódico; iii) separação de poderes, e; iv) os direitos e garantias individuais. Como podemos analisar pela leitura das matérias tratadas podemos considerar que essas são as matérias fundamentais do Poder Constituinte originário e que são fruto de uma decisão política da sociedade que erigiu estas regras como os valores fundamentais do nosso ordenamento jurídico.

A forma federativa do Estado brasileiro é tema que faz parte da história constitucional brasileira, haja vista que todas as constituições que foram promulgadas no período Republicano, a exceção da Constituição de 1937 (denominada "Polaca", haja vista que foi inspirada na Constituição da Polônia igualmente pouco democrática), trouxeram expressamente previsto no corpo do texto constitucional a proibição da abolição da forma federativa do Estado, ou seja, trata-se de norma constitucional que já está como um dos fundamentos principais do Estado brasileiro.

Devemos reconhecer que o objetivo desta norma é garantir a unidade do país e a descentralização política permitindo que os cidadãos fiquem mais próximos dos representantes dos entes, afastando alguns dos incômodos que podem ocorrem em geral nos Estados unitários (onde existe apenas o poder central e há maior distanciamento dos cidadãos com os seus representantes).

Embora haja a garantia da federação como uma das normas fundamentais do nosso ordenamento jurídico, podemos criticar no plano político a pouca autonomia que os Estados-Membros (e o Distrito Federal) e também os Municípios (em especial os Municípios de regiões pobres do país com poucos habitantes, poucos recursos, etç), detém em face do poder

$\S 4^{\text {o }}$ - Não será objeto de deliberação a proposta de emenda tendente a abolir:

I - a forma federativa de Estado;

II - o voto direto, secreto, universal e periódico;

III - a separação dos Poderes;

IV - os direitos e garantias individuais. 
central da União, haja vista que a nossa Carta Constitucional centralizou excessivamente a competência legislativa na União Federal (art. 22 da CF 88) e em especial a competência tributária para instituição e arrecadação de tributos (art. 153 da CF 88).

Não vamos nos estender acerca do tema, tendo em vista os estritos limites do nosso objeto de estudo, porém convém numa abordagem crítica reconhecer que a forma federativa precisa ser melhor reforçada em nosso ordenamento jurídico para permitir uma maior descentralização política e econômica gerando, portanto, maior eficiência na alocação dos recursos. No que nos compete destacar com fundamento no nosso objeto de estudo é que o princípio federativo é extremamente caro ao legislador constituinte originário brasileiro e assim o é historicamente, razão pela qual qualquer emenda constitucional tendente a enfraquecer este princípio federativo deve ser considerado como inconstitucional pelo Poder Judiciário.

De igual modo, também é considerada como "cláusula pétrea" do nosso ordenamento jurídico o legítimo exercício do voto direto, secreto, universal e periódico, como forma de salvaguardar o exercício pelos cidadãos dos seus direitos políticos e como proteção ao regime democrático, tão caro ao nosso legislador constituinte originário, em especial após o transcurso do período de 24 anos (1964 à 1988) de um regime que não respeitava a democracia, não garantia aos cidadãos o exercício pleno de seus direitos políticos.

Essas características importam em diversas limitações materiais impostas ao legislador constituinte derivado, que não poderiam instituir, por exemplo o voto censitário. Igualmente está proibida a edição de emenda constitucional para tornar determinados cargos públicos políticos em vitalícios (como tivemos já exemplos no direito estrangeiro, como o senador vitalício Augusto Pinhochet no Chile), dentre outras diversas limitações decorrentes desta regra constitucional. 
Outra "cláusula pétrea" que serve como limitação material ao Poder Constituinte derivado é a impossibilidade de edição de emendas constitucionais tendentes a abolir a "separação dos poderes" prevista no art. 2 da Constituição Federal de $1988^{131}$ que prevê expressamente como poderes da União o Poder Executivo, o Poder Legislativo e o Poder Judiciário, que devem ser necessariamente independentes e harmônicos entre si.

A necessidade da separação dos poderes foi muito estudada pelos teóricos da ciência política e também pelos constitucionalistas que reconheceram que a separação dos poderes é um elemento essencial para o regular funcionamento da sociedade e como elemento que auxilia na prevenção dos abusos do poder estatal em face dos cidadãos, permitindo que a relação jurídica entre o Estado e os indivíduos seja cada vez mais uma relação jurídica entre governantes e governados, entre Estado e cidadão e não entre soberanos e súditos. Seguindo essa linha de raciocínio, a Declaração Universal dos Direitos do Homem e do Cidadão (de certa forma até radical) em seu art. $16^{132}$ prevê que "Toda a sociedade onde não está assegurada a garantia dos direitos nem tem separação de poderes não tem constituição".

Por fim, impende salientar que todas as Constituições da história constitucional brasileira previram a obrigatoriedade da separação dos poderes, inclusive, a Constituição Imperial de 1824 (que também incluía o Poder Moderador na pessoa do Imperador), embora apenas a Constituição Federal de 1988 tenha previsto de forma expressa que este princípio faz parte do "núcleo imodificável" e que não pode ser objeto de reforma pelo legislador constituinte derivado.

\footnotetext{
${ }^{131}$ Art. 2 CF 88: São Poderes da União, independentes e harmônicos entre si, o Legislativo, o Executivo e o Judiciário.

${ }^{132}$ Art. 16 Declaração dos Direitos do Homem: Qualquer sociedade em que não esteja assegurada a garantia dos direitos, nem estabelecida a separação dos poderes não tem Constituição.
} 
A última das "cláusulas pétreas" expressamente prevista pelo legislador constituinte originário é atinente a vedação que é imposta ao Poder Constituinte derivado para efetuar alterações no texto constitucional que impliquem na violação aos direitos e garantias individuais.

Com efeito, resta claro que é vedado ao legislador constituinte derivado, por exemplo, criar normas que limitem a proteção ao domicílio, nem restringir de qualquer outro modo outras garantias individuais fundamentais.

Questão relevante a ser debatida é saber se outras espécies de direitos individuais também estariam incluídos no rol de "clausulas pétreas", como os direitos sociais. A melhor interpretação é no sentido que a interpretação a ser efetuada pelo exegeta deve ser a mais ampla possível para incluir como "cláusulas pétreas" todos os direitos fundamentais dos cidadãos, dentre eles os direitos sociais, haja vista que esta interpretação constitucional se compatibiliza mais com a lógica do ordenamento jurídico pátrio. Por outro lado, devemos considerar que o "princípio da dignidade humana", que é inspirado na doutrina alemã, para a grande maioria da doutrina constitucionalista funciona como vértice norteador do nosso ordenamento jurídico e deve ser utilizado como forma adequada para que seja identificado o real alcance da Constituição. Tendo em vista esta afirmação é perfeitamente plausível a inclusão dos direitos sociais como aqueles direitos individuais previstos como "núcleo imodificável", razão pela qual não é possível que o Poder Constituinte derivado elabore normas tendentes a enfraquecer ou à abolir estes direitos.

\subsubsection{0. - As limitações Temporais ao Poder de Reforma da Constituição.}

É despiciendo tecer maiores considerações acerca das limitações temporais ao Poder Constituinte, à luz do atual ordenamento jurídico vigente, haja vista que a Constituição Federal de 1988 não previu de forma 
expressa qualquer espécie de limitação temporal para efetuar a reforma da Constituição.

Devemos ressaltar que na história constitucional brasileira, a Constituição de $1824 \mathrm{em}$ seu art. $174^{133}$, previu expressamente que não seria lícito ao legislador constituinte derivado efetuar a reforma da Constituição no período de 4 anos a contar da sua promulgação.

No âmbito do direito estrangeiro, podemos destacar a Constituição Portuguesa de 1976 que apenas possibilita a edição de "Lei de Revisão" após 5 anos da promulgação da Constituição.

O objetivo principal dessa limitação à reforma constitucional possui natureza política e objetiva garantir maior estabilidade ao texto constitucional elaborado pelo legislador constituinte originário, objetivando a incorporação na vida social da Constituição, não permitindo a alteração do texto constitucional em breve período de tempo para evitar que o descrédito da norma constitucional em razão das suas alterações, ou seja, objetiva a "solidificação da legalidade democrática"134.

A crítica que pode ser efetuada a esse tipo de limitação é que há uma vinculação da sociedade, ainda que por curto período de tempo, há preceitos constitucionais elaborados pelo Poder Constituinte originário que podem não estar de acordo com a realidade social dos cidadãos de determinado Estado o que em última análise pode culminar, em casos de graves crises políticas, na formação de uma nova constituinte para elaboração de um novo texto constitucional.

\subsubsection{1. - As limitações Circunstanciais ao Poder de Reforma}

\section{da Constituição.}

\footnotetext{
133 Art. 174 CF 1824: Se passados quatro annos, depois de jurada a Constituição do Brazil, se conhecer, que algum dos seus artigos merece roforma, se fará a proposição por escripto, a qual deve ter origem na Camara dos Deputados, e ser apoiada pela terça parte delles.

${ }^{134}$ CANOTILHO, José Joaquim Gomes. Direito Constitucional e Teoria da Constituição. 7 ed. Coimbra: Editora: Livraria Almedina. p. 944-945.
} 
Em algumas situações de grave instabilidade política o legislador constituinte originário considerou que não é adequado proceder a reforma constitucional para evitar que se coloque em risco a estabilidade constitucional.

No âmbito da Constituição Federal de 1988 esta limitação circunstancial está estabelecida no art. $60, \quad \S 1 .{ }^{135}$ que dispõe a impossibilidade de emenda à constituição na hipótese de: i) intervenção federal; ii) estado de defesa,e ; iii) estado de sítio.

A intervenção federal é uma das medidas mais graves que foram previstas pelo ordenamento constitucional, a excepcionalidade e a gravidade da adoção desta medida é tão evidente que a redação do caput do art. 34 da Constituição Federal ${ }^{136}$ dispõe que a União Federal não intervirá, salvo nas hipóteses elencadas nos incisos do aludido artigo.

Não convém discorrer detalhadamente acerca das diferentes hipóteses que podem ensejar a intervenção federal da União Federal nos Estados-Membros, mas convém salientar que em qualquer uma das hipóteses destacadas abaixo, previstas no art. 34 da Constituição Federal de 1988, o legislador constituinte derivado não poderá proceder à reforma da Constituição:

“Art. 34. A União não intervirá nos Estados nem no Distrito Federal, exceto para:

\footnotetext{
135 Art. 60, §1, CF 88: A Constituição poderá ser emendada mediante proposta: (...)

$\S 1^{\circ}$ - A Constituição não poderá ser emendada na vigência de intervenção federal, de estado de defesa ou de estado de sítio.

${ }^{136}$ Art. 34 CF 88: A União não intervirá nos Estados nem no Distrito Federal, exceto para:

I - manter a integridade nacional;

II - repelir invasão estrangeira ou de uma unidade da Federação em outra;

III - pôr termo a grave comprometimento da ordem pública;

IV - garantir o livre exercício de qualquer dos Poderes nas unidades da Federação;

V - reorganizar as finanças da unidade da Federação que:

a) suspender o pagamento da dívida fundada por mais de dois anos consecutivos, salvo motivo de força maior;

b) deixar de entregar aos Municípios receitas tributárias fixadas nesta Constituição, dentro dos prazos estabelecidos em lei;

VI - prover a execução de lei federal, ordem ou decisão judicial;

VII - assegurar a observância dos seguintes princípios constitucionais:
} 
I - manter a integridade nacional;

II - repelir invasão estrangeira ou de uma unidade da Federação em outra;

III - pôr termo a grave comprometimento da ordem pública;

IV - garantir o livre exercício de qualquer dos Poderes nas unidades da Federação;

V - reorganizar as finanças da unidade da Federação que:

a) suspender o pagamento da dívida fundada por mais de dois anos consecutivos, salvo motivo de força maior;

b) deixar de entregar aos Municípios receitas tributárias fixadas nesta Constituição, dentro dos prazos estabelecidos em lei;

VI - prover a execução de lei federal, ordem ou decisão judicial;

VII - assegurar a observância dos seguintes princípios constitucionais:

a) forma republicana, sistema representativo e regime democrático;

b) direitos da pessoa humana;

c) autonomia municipal;

d) prestação de contas da administração pública, direta e indireta.

e) aplicação do mínimo exigido da receita resultante de impostos estaduais, compreendida a proveniente de transferências, na manutenção e desenvolvimento do ensino e nas ações e serviços públicos de saúde. (Redação dada pela Emenda Constitucional no 29 , de 2000)"

De igual modo na hipótese em que for declarado estado de defesa não será possível proceder a reforma da Constituição. Nesse sentido confira-se a disposição contida no art. 136 da Constituição Federal:

“Art. 136. O Presidente da República pode, ouvidos o Conselho da República e o Conselho de Defesa Nacional, decretar estado de defesa para preservar ou prontamente restabelecer, em locais restritos e determinados, a ordem pública ou a paz social ameaçadas por grave e iminente instabilidade institucional ou atingidas por calamidades de grandes proporções na natureza.”.

Por fim, as mesmas observações acerca das limitações circunstanciais ao poder de reforma destacadas se aplicam também na hipótese de ser decretado estado de sítio, tal como previsto no art. 137 da Constituição Federal: 
“Art. 137. O Presidente da República pode, ouvidos o Conselho da República e o Conselho de Defesa Nacional, solicitar ao Congresso Nacional autorização para decretar o estado de sítio nos casos de:

I - comoção grave de repercussão nacional ou ocorrência de fatos que comprovem a ineficácia de medida tomada durante o estado de defesa;

II - declaração de estado de guerra ou resposta a agressão armada estrangeira.

Parágrafo único. O Presidente da República, ao solicitar autorização para decretar o estado de sítio ou sua prorrogação, relatará os motivos determinantes do pedido, devendo o Congresso Nacional decidir por maioria absoluta."

\subsubsection{2. - As limitações Formais ao Poder de Reforma da} Constituição.

Os limites formais ao "Poder Constituinte derivado" são aqueles limites relacionados ao procedimento de alteração do texto constitucional e também as formalidades impostas pelo legislador constituinte originário impôs ao legislador constituinte derivado.

Nesse sentido, confira-se a definição apresentada pelo professor lusitano Gomes Canotilho ${ }^{137}$ :

"Os processos específicos de modificação da Constituição baseiam-se essencialmente nas várias formas de participação popular, nas alterações constitucionais, na escolha do órgão a quem é atribuído o poder de revisão, na exigência de um iter processual mais complexo do que o processo legislativo normal, e no exercício temporal do poder de revisão".

No âmbito da doutrina constitucionalista pátria o professor André Ramos Tavares ${ }^{138}$ destaca o caráter eminentemente processualista (processo legislativo) dessas restrições e discorre sobre o processo de elaboração das emendas constitucionais:

“Assim, têm-se as denominadas restrições processuais, que são aquelas referentes ao próprio processo da elaboração da emenda constitucional. Trata-se de um primeiro nível de limitações a essa competência constitucional reformadora, que, portanto, encontra plena regulamentação jurídica, ao contrário do que ocorre com o poder constituinte (art. 60). Dizem respeito à competência, iniciativa, quórum

\footnotetext{
${ }^{137}$ CANOTILHO, José Joaquim Gomes. Direito Constitucional e Teoria da Constituição. 7 ed. Coimbra: Editora: Livraria Almedina, 2003.p. 938.

${ }^{138}$ TAVARES, Andre Ramos. Curso de Direito Constitucional. São Paulo: Editora: Saraiva, 2002. p. 49.
} 
para aprovação etc. Essas cláusulas não podem ser alteradas pelo poder de reforma, ainda que com obediência ao processo previsto à época (mudanças dos requisitos formais para o futuro)."

Nesse sentido, devemos considerar, seguindo o magistério do professor Alexandre de Moraes ${ }^{139}$ que no âmbito da Constituição Federal de 1988 as "limitações formais" (aquelas referentes ao processo legislativo) ao poder de reforma da Constituição encontram-se inseridas nos art.60, I, II e III, $\S 2^{\circ}, \S 3^{\circ}$ e $\S 5^{\circ}$ :

Art. 60 CF: A Constituição poderá ser emendada mediante proposta:

I - de um terço, no mínimo, dos membros da Câmara dos Deputados ou do Senado Federal;

II - do Presidente da República;

III - de mais da metade das Assembléias Legislativas das unidades da Federação, manifestando-se, cada uma delas, pela maioria relativa de seus membros.

(...)

$\S 2^{\circ}$ - A proposta será discutida e votada em cada Casa do Congresso Nacional, em dois turnos, considerando-se aprovada se obtiver, em ambos, três quintos dos votos dos respectivos membros.

$\S 3^{\circ}$ - A emenda à Constituição será promulgada pelas Mesas da Câmara dos Deputados e do Senado Federal, com o respectivo número de ordem.

(...)

$\S 5^{\circ}$ - A matéria constante de proposta de emenda rejeitada ou havida por prejudicada não pode ser objeto de nova proposta na mesma sessão legislativa.

Podemos observar pela leitura do texto constitucional acima citado que o legislador constituinte originário dispôs de forma expressa sobre os órgãos legítimos pra procederem a alteração do texto constitucional (Presidente da República, por meio de iniciativa de um terço dos representantes das casas do Congresso Nacional - Câmara dos Deputados e Senado Federal - e também pela iniciativa de mais da metade das Assembleias Legislativas dos Estados da Federação, em prestígio ao princípio federativo).

\footnotetext{
${ }^{139}$ MORAES, Alexandre de, Direito Constitucional. 21 ed . São Paulo: Editora: Atlas, 2007. p. 637.
} 
Não é licito a elaboração de emenda constitucional para incluir outros órgãos não incluídos pelo legislador constituinte originário, haja vista que não é lícito ao legislador constituinte derivado exercer mais poderes dos que lhe foram outorgados pelo Poder Constituinte originário. De igual modo, a doutrina constitucionalista preceitua que é viável a elaboração de emendas à Constituição para efetuar alterações procedimentais que tornem mais rigoroso o processo de mudança do texto constitucional, haja vista que nesta hipótese estaria mantida proteção aos princípios da "supremacia da Constituição" e da "rigidez constitucional". Nesse sentido, não seria inconstitucional, por exemplo, projeto de emenda à Constituição que alterasse o texto constitucional para determinar a exigência de iniciativa de dois terços dos membros da Câmara dos Deputados ou do Senado Federal para possibilitar a emenda à constituição. 


\section{Conclusão}

É essencial o estudo das "limitações ao poder de reforma do texto constitucional", haja vista que principalmente nos países com democracias poucos consolidadas, do ponto de vista da história institucional, como no caso do Brasil, é comum que em face de qualquer instabilidade política os governantes de plantão se arvorem a apontar a elaboração de uma nova Constituição como a solução "mágica" para todos os problemas sociais que acometem o povo. Essa "cultura jurídica" e "política" dos governantes é extremamente prejudicial, haja vista que gera extrema insegurança jurídica para todos aqueles que convivem com aquele Estado.

Nesse diapasão o estudo teórico do "Poder Constituinte", longe de ser um problema "excessivamente acadêmico" é um problema real e prático que merece a atenção dos juristas e demais operadores do direito, tendo em vista que é a própria legitimidade da ordem jurídica que "está em jogo". Deve haver uma intransigente defesa dos direitos fundamentais de modo a reconhecer que apenas o "povo" como legítimo titular para proceder a ruptura do ordenamento jurídico e não devemos considerar a existência de legitimidade de algumas minorias ocasionais para proceder a uma "revolução" alegando representar o povo para posteriormente subjugá-lo ao império das leis constitucionais.

De igual modo, deve ser reconhecido que a doutrina constitucionalista majoritária aponta para o enfraquecimento do caráter absoluto da "incondicionalidade" do Poder Constituinte originário. Em que pese o tema não ser de estudo recorrente pelos constitucionalistas, deve ser reconhecida a "vedação ao retrocesso" que vincula até mesmo ao titular do "Poder Constituinte originário", pois, não é lícito a elaboração de uma nova Carta Constitucional, ainda que exercida regularmente pelo seu titular (o "povo") mas que contrarie os valores históricos, sociais, culturais de determinada sociedade. Ao nosso sentir, não será lícita na eventual elaboração de uma nova Carta Constitucional a estipulação de "pena de 
morte" para crimes hediondos ou "penas de caráter perpétuo". Essas normas penais, por exemplo, embora gozem de ampla aprovação popular violam sobremaneira os Tratados Internacionais aos quais o Brasil está vinculado, em especial os Tratados Internacionais que versam sobre a proteção dos Direitos Humanos, além de irem de encontro com os valores institucionalizados pelo nosso legislador constituinte originário ao longo de nossa história constitucional.

Tal afirmação é devida, haja vista que na eventual elaboração de uma Constituição que viola os preceitos fundamentais dos cidadãos deve ser exercido o legítimo "direito de resistência” e a ordem jurídica que se impôs deve ser reconhecida como "ilegítima", tal como podemos citar, como exemplo recente, as Constituições de 1967 e de 1969 (emenda constitucional n. 1 à Constituição de 1967) que se demonstraram como claros retrocessos na nossa história constitucional e que foram combatidas pela sociedade ao longo de 24 (árduos) anos.

Por outro lado, devemos reconhecer que muitas vezes o Poder Constituinte originário é fruto de um legítimo esforço da sociedade e o seu trabalho, a "Constituição", acaba por se tornar uma obra jurídica que privilegia a dignidade humana, os direitos sociais, dentre outros valores que são caros para os cidadãos, como felizmente ocorreu com a promulgação da Constituição brasileira de 1988.

Entretanto, devemos ter em mente, e o estudo empírico demonstra isso, que não basta elaborar uma "Constituição jurídica" que contemple diversos direitos e garantias aos cidadãos que não são contemplados na “Constituição real” do povo. É papel e dever de todo o jurista, de todo o operador do direito, conscientizar a sociedade para que haja de forma cada vez maior a aplicabilidade dos preceitos constitucionais, visando impedir que o "Estado de Exceção" continue a exercer influência no "Estado de Direito". 
Por outro turno, indo além da questão da eficácia e da aplicabilidade das normas constitucionais, deve ser ressaltado que o processo de reforma do texto constitucional objetiva adequar a realidade social ao que está estipulado na "Constituição jurídica" e não pode ser usado pelas forças de "Estado de exceção" que de fato existe no cenário político nacional e são bem representadas, inclusive no Congresso Nacional. Para comprovar essa tese basta, por exemplo, analisar as "PECs" que preveem a possiblidade da adoção da pena de morte para crimes hediondos, ou a possibilidade de alteração do texto constitucional para possibilitar a prisão perpétua, ou aquelas que visam diminuir ou malbaratar os direitos e garantias individuais e sociais que foram duramente conquistados pelo titular do Poder Constituinte originário (o "povo") por ocasião da promulgação da Constituição Federal “cidadã” de 1988.

Nesse sentido, essencial que sejam preservadas as limitações constitucionais estipuladas pelo legislador Constituinte originário, conforme estudado ao longo da presente monografia, para que possa ser garantido no plano jurídico e no plano real o que é realmente essencial, os direitos fundamentais dos cidadãos que podem ser resumidos como na proteção do princípio constitucional da dignidade humana. 


\section{Bibliografia}

MENDES, Gilmar Ferreira \& BRANCO, Paulo Gustavo Gonet. Curso de Direito Constitucional. 8 ed. revisada e atualizada. São Paulo: Editora: Saraiva, 2013. p. 37.

MENDONÇA, Daniel. Analisis constitucional: uma introducción cómo hacer cosas com la Constitución,Bogotá, Editora: Editoral Universidade del Rosario, 2002.

TAVARES, Andre Ramos. Curso de Direito Constitucional. São Paulo: Editora: Saraiva, 2002.

ZIMMERMANN, Augusto. Curso de Direito Constitucional. 3 ed. Rio de Janeiro: Editora Lumen Juris, 2004.

BASTOS, Celso Ribeiro; MARTINS, Ives Gandra, Comentários á Constituição do Brasil. São Paulo: Editora Saraiva, 1988, v. 1.

MORAES, Alexandre de, Direito Constitucional. 21 ed . São Paulo: Editora: Atlas, 2007.

NEGRI, Antonio. O poder constituinte: ensaio sobre alternativas da modernidade, traduação Adriano Pilatti. Rio de Janeiro: Editora DPeA, 2002.

CARRIÓ, Genaro R.,Notas sobre Derecho y Lenguage. 4 ed., Buenos Aires: Editora: Abeledo Perrot, 1990.

DA SILVA, José Afonso, Curso de Direito Constitucional positivo, 35 ed. São Paulo. Editora: Malheiros, 2012.

CHIRADIA, Tatiana Del Giudice Cappa, A essência do Poder Constituinte. Dissertação de Mestrado PUC-SP, Orientador: Professor Doutor Antônio Carlos Mendes, São Paulo, 2009. 
VANOSSI, Jorge Reinaldo A., Uma visão atualizada do Poder Constituinte. Revista de Direito Constitucional e ciência política, v. 4.

KELSEN, Hans, Teoria Geral do Direito e do Estado.Trad. por Luís Carlos Borges. 4 ed. São Paulo: Editora: Martins Fontes, 2005.

BONAVIDES, Paulo, Curso de Direito Constitucional. 6 ed., São Paulo: Editora:Malheiros Editora LTDA., 1996.

CANOTILHO, José Joaquim Gomes. Direito Constitucional e Teoria da Constituição. 7 ed. Coimbra: Editora: Livraria Almedina, 2003.

DALLARI, Dalmo de Abreu, A constituição na vida dos povos: da Idade Média ao século XXI. São Paulo: Editora: Saraiva, 2010.

HESS, Konrad, A Força Normativa da Constituição. Tradução: Gilmar Ferreira Mendes, Porto Alegre, Editora: Sergio Antonio Fabris, 1991.

LASSALE, Ferdinand, Discours et pamphlets - De l' essence d'une Constituion. Paris: Giard - Briére, 1903.

AGUIAR VIEIRA, Yacir de, A essência da Constituição no pensamento de Lassale e de Konrad Hesse. Brasília a, 35, n.139 jul./set. 1998

VON JHERING, Rudolf, A luta pelo Direito. Tradução João de Vasconcelos, Rio de Janeiro: Editora: Forense, 1972.

SYÉYÉS, Emmanuel, Qu'est-ce que le Tiers Etat?. França, Quadrige/Presses Universitaires de France, 1982.

GUIMARAENS, Francisco De. O poder constituinte no conceito de Antonio Negri - Um conceito muito além da Modernidade hegemônica/ orientador: Carlos Alberto Plastino, Co-Orientador: Adriano Pilatti - Rio de Janeiro, Departamento de Direito, 2002. 
TEIXEIRA, José Horácio Meireles, Curso de Direito Constitucional, Texto revisto e atualizado por Maria Garcia. Rio de Janeiro: Editora: Forense Universitária.

BONIFÁCIO, Artur Cortez. Limitações Materiais ao Poder Constituinte Originário, Revista de Direito Constitucional e Internacional. Ano 11. n. 42 - janeiro -março 2003.

MENDONÇA, José Vicente dos Santos. A vedação do retrocesso: o que é e como perder o medo. In: Gustavo BINENBOJN (Coord.), Revista de Direito da Associação dos Procuradores do Novo Estado do Rio de Janeiro, v. XII.

Consulta disponível no sítio da Câmara dos Deputados: $<$ http://http://www.camara.gov.br/proposicoesWeb/fichadetramitacao?idPro posicao $=457071>$. Acesso em 02 de novembro de 2014.

FERREIRA FILHO, Manoel Gonçalves, O poder constituinte. 3 ed. São Paulo: Editora: Saraiva, 1999.

CUNHA FERRAZ, Ana Candida, Poder Constituinte do EstadoMembro, in Enciclopédia Saraiva do Direito, São Paulo: Editora: Saraiva, 1981, v. 59.

SARLET, Ingo Wolfgaang, Dignidade da pessoa humana e direitos fundamentais na Constituição Federal de 1988, 4 ed. ver. Atual. - Porto Alegre: Editora: Livraria do Advogado, 2006.

ANTUNES ROCHA, Carmen Lúcia, Constituição e mudança constitucional: limites ao poder de reforma constitucional, Revista de Informação Legislativa, Brasília, out/ dezembro de 1993, n. 120.

SAMPAIO, Nelson de Souza. O poder de Reforma Constitucional. 3 ed. Belo Horizonte. Editora: Nova Alvorada edições, 1995. 
MIRANDA, Jorge, Manual de Direito Constitucional. TOMO II. Introdução a teoria da Constituição.2 ed. Coimbra: Editora: Coimbra. 1983. 